\title{
The adverse effects of obesity on conception and implantation
}

\author{
Christopher J Brewer and Adam H Balen \\ The Leeds Centre for Reproductive Medicine, Seacroft Hospital, Leeds Teaching Hospitals NHS Trust, Leeds, \\ LS14 6UH, UK \\ Correspondence should be addressed to A H Balen; Email: adam.balen@leedsth.nhs.uk
}

\begin{abstract}
Whilst many multiparous women are obese (body mass index $>30 \mathrm{~kg} / \mathrm{m}^{2}$ ), obesity has been associated with impaired fecundity; however, the mechanism which links obesity to reduced fertility remains to be fully elucidated. Obese women, particularly those with central obesity, are less likely to conceive per cycle. Obese women suffer perturbations to the hypothalamic-pituitary-ovarian axis, menstrual cycle disturbance and are up to three times more likely to suffer oligo-/anovulation. A fine hormonal balance regulates follicular development and oocyte maturation, and it has been observed that obesity can alter the hormonal milieu. Leptin, a hormone produced by adipocytes, is elevated in obese women, and raised leptin has been associated with impaired fecundity. Obesity impairs ovulation but has also been observed to detrimentally affect endometrial development and implantation. The expression of polycystic ovary syndrome (PCOS) is regulated, in part, by weight, and so obese women with PCOS often have a more severe phenotype and experience more subfertility. Obesity also impairs the response of women to assisted conception treatments. Weight loss through lifestyle modification or bariatric surgery has been demonstrated to restore menstrual cyclicity and ovulation and improve the likelihood of conception. In this article, we will discuss the effect of obesity upon key reproductive mechanisms and its relation to fertility treatments. Reproduction (2010) 140 347-364
\end{abstract}

\section{The adverse effects of obesity on conception and implantation}

Obesity is an increasingly prevalent health burden upon modern society. Most obese women are not infertile; however, obesity and its negative impact upon fecundity and fertility are well documented. Obese women are three times more likely to suffer infertility than women with a normal body mass index (BMI; Rich-Edwards et al. 1994). Obese women experience impaired fecundity both in natural and assisted conception cycles (Zaadstra et al. 1993, Crosignani et al. 1994). The mechanism through which its effect is exerted is more controversial. Obesity is characterised by excess lipid storage. Definitions of obesity can vary, but the most widely accepted definition adheres to the WHO BMI $\left(\mathrm{kg} / \mathrm{m}^{2}\right)$ criteria. A person is obese if his/her $\mathrm{BMI}$ is $\geq 30 \mathrm{~kg} / \mathrm{m}^{2}$. There are degrees of obesity: class $1\left(30.0-34.9 \mathrm{~kg} / \mathrm{m}^{2}\right)$, class 2 $\left(35.0-39.9 \mathrm{~kg} / \mathrm{m}^{2}\right)$ and class $3\left(\geq 40 \mathrm{~kg} / \mathrm{m}^{2}\right)$. Alternative, although less commonly used, parameters for the assessment of obesity include waist circumference and waist:hip ratio (WHR). A waist circumference $>80 \mathrm{~cm}$ in women is an accepted indicator of visceral fat accumulation (Tamer Erel \& Senturk 2009).

This paper is one of five papers that form part of a special Focus Issue section on Obesity. The Guest Editor for this section was J E Norman, Edinburgh, UK.
Population studies demonstrate an increasing prevalence of overweight and obese women, and maternal obesity detected an increase from 9.9 to $16.0 \%$ from 1990 to 2005 (Lewis 2007, Heslehurst et al. 2007). It has been proposed that obesity impairs fertility through an effect upon the control of ovulation, oocyte development, embryo development, endometrial development, implantation and pregnancy loss. This article aims to summarise the current understanding of how obesity might affect these processes in the context of natural and assisted conception.

\section{Obesity and impaired reproductive potential}

The negative effect of obesity upon fertility was described by Hippocrates, who wrote in his Essay on the Scythians 'People of such constitution cannot be prolific ...fatness and flabbiness are to blame. The womb is unable to receive the semen and they menstruate infrequently and little' (Lloyd et al. 1978). Putative causes for conception delay in obese women can conceptually be categorised as pathophysiological, psychosocial and sociobiological. The bulk of this article will pertain to the pathophysiological aspects. However, the psychosocial and sociobiological aspects will touched upon at the end of this section.

Several population-based studies have shown subfecundity in overweight and obese women. The Nurses' 
Health Study compared 2527 married nulliparous women with anovulatory subfertility of 1 year with 46718 married multiparous women with no history of subfertility. Multivariate analysis determined the relative risk of infertility for each BMI category, and the relative risks were reported as follows: $1.2\left(\mathrm{BMI}<16 \mathrm{~kg} / \mathrm{m}^{2}\right)$, 1.1 (BMI 16-17.9 kg/m²), 1.0 (BMI 18-19.9 kg/m²), 1.0 (referent BMI $\left.20-21.9 \mathrm{~kg} / \mathrm{m}^{2}\right), 1.1$ (BMI $22-23.9 \mathrm{~kg} / \mathrm{m}^{2}$ ), 1.3 (BMI 24-25.9 kg/m²), 1.7 (BMI 26-27.9 kg/m²), 2.4 (BMI 28-29.9 kg/m²), 2.7 (BMI $30-31.9 \mathrm{~kg} / \mathrm{m}^{2}$ ) and 2.7 (BMI $\geq 32 \mathrm{~kg} / \mathrm{m}^{2}$ ). Therefore, above 23.9, the relative risk of subfertility was statistically significantly elevated (Rich-Edwards et al. 1994). Similarly, Grodstein et al. (1994) demonstrated a higher prevalence of anovulatory subfertility among the obese women. They compared 597 anovulatory women with 1695 primiparous controls; the relative risk of anovulatory subfertility in the obese women (defined in this study as BMI $>27 \mathrm{~kg} / \mathrm{m}^{2}$ ) was 3.1 (95\% confidence interval $(\mathrm{Cl}) 2.2-4.4)$ when compared to those with a normal BMI $\left(20-24.9 \mathrm{~kg} / \mathrm{m}^{2}\right.$; Grodstein et al. 1994). A similar effect has been demonstrated in an observational study of 2112 consecutive pregnant women to investigate lifestyle factors that might impair fecundity, and a BMI $>25 \mathrm{~kg} / \mathrm{m}^{2}$ was significantly correlated with a prolongation of time to pregnancy (Hassan \& Killick 2004).

Body fat distribution also has important reproductive ramifications, and central obesity as defined by an increased waist circumference or by an elevated WHR has been observed to have a negative impact on fecundity. A Dutch study monitored the effect of obesity upon fecundity in a donor insemination programme; 500 women were prospectively monitored. They observed that a 0.1 unit increase in WHR led to a $30 \%$ decrease in probability of conception per cycle (hazard ratio 0.706 ; 95\% Cl 0.562-0.887; Zaadstra et al. 1993).

Obesity can exert effects upon the hypothalamicpituitary-ovarian (HPO) axis and as such disturb menstrual cyclicity and ovulation. A large questionnaire study of 26638 women demonstrated that menstrual cycle irregularity and anovulation were correlated with being overweight or obese. Indeed, the grossly obese women had a rate of menstrual disturbance 3.1 times that of women with normal weight (Hartz et al. 1979). The effect of obesity (childhood and adult) on menstrual cyclicity was demonstrated in a longitudinal study of 5799 British women born in 1958. Obesity in childhood (age 7 years) and in early adulthood (age 23 years) was predictive of increased chance of current menstrual cycle disturbance (odds ratio (OR) 1.59 and 1.75 respectively). Likewise, when young obese women (age 23 years) were compared to women with normal weight, they were less likely to conceive, $\mathrm{OR}=0.69$ (Lake et al. 1997). Whilst several studies have proposed disturbance to the HPO axis as a key pathophysiological factor in subfecundity in the obese women, impaired fertility has been demonstrated in obese women with normal menstrual cyclicity. A retrospective analysis of US data collected as part of the Collaborative Perinatal Project demonstrated a reduced fecundity for overweight (BMI $25.0-29.9 \mathrm{~kg} / \mathrm{m}^{2} ; \mathrm{OR}=0.92,95 \%$ $\mathrm{Cl}$ 0.84-1.01) and obese (BMI $\geq 30 \mathrm{~kg} / \mathrm{m}^{2}$ ) women $(\mathrm{OR}=0.82,95 \% \mathrm{Cl} 0.72-0.95)$. Fecundity remained reduced in overweight and obese women when only women with normal menstrual cycles were considered (Gesink Law et al. 2007).

Weight loss programmes have been observed to restore normal menstrual cyclicity, and an Australian group demonstrated the important role of weight loss in the management of obese anovulatory infertile women (Clark et al. 1995). Obese women who had not responded to clomiphene citrate were enrolled into a 6-month programme of weight loss by exercise and dietary change; the average weight loss was $6.3 \mathrm{~kg}$. Resumption of ovulation was observed in 12 of the 13 women, and remarkably, 11 of these conceived (5 natural conceptions and 6 who were now responsive to ovulation induction with clomiphene citrate). In a follow-up study by the same group, data for 67 of 87 women who were enrolled in a weight loss programme were analysed. As previously, an encouraging proportion demonstrated resumption of natural ovulation (60 of 67) and 52 pregnancies (45 live births; Clark et al. 1998). In the same study, the cost effectiveness of a provider-led weight-loss programme was demonstrated, and it was calculated that the cost per baby before the programme was $A \$ 275000$, whereas following the programme, the cost per baby was estimated to be $A \$ 4600$. This reduction was in part due to the reduction in reliance on assisted conception techniques and increased efficacy should they be required. Hollmann et al. (1996) demonstrated a significant increase in eumenorrhoeic women, after a cohort of obese women followed a weight-reducing diet. More recently, a study of 143 obese women with polycystic ovary syndrome (PCOS) has demonstrated that weight loss through lifestyle changes alone significantly improved menstrual frequency (Tang et al. 2006).

Obese women are more likely to experience pregnancy loss once pregnant, and elevated miscarriage rates are seen following natural conception, ovulation induction and assisted conception. A retrospective analysis of women with PCOS undergoing ovulation induction demonstrated an increased frequency of miscarriage among obese women (BMI $>28 \mathrm{~kg} / \mathrm{m}^{2}$ ) when compared to normative controls (60 vs $27 \%$, $P<0.05$; Hamilton-Fairley et al. 1992). A retrospective analysis of 5019 IVF/ICSI cycles in 2660 women in a Norwegian clinic observed a linear association between higher BMI and early pregnancy loss ( $<6$ weeks) and miscarriage (6-12 weeks). The OR for early pregnancy loss was $1.69(95 \% \mathrm{Cl} 1.13-2.51, P=0.003)$ in obese women $\left(\mathrm{BMI}>30 \mathrm{~kg} / \mathrm{m}^{2}\right)$ compared with women with 
normal weight (Fedorcsak et al. 2004). A recent meta-analysis demonstrated an increased risk of miscarriage among obese women (BMl $>30 \mathrm{~kg} / \mathrm{m}^{2}$ ) undergoing assisted conception (IVF/ICSI; OR $=1.53$, 95\% Cl 1.27-1.84; Maheshwari et al. 2007). A further meta-analysis also found that patients with a BMI $>25 \mathrm{~kg} / \mathrm{m}^{2}$ were found to have a significantly elevated odds of miscarriage regardless of the mode of conception $(\mathrm{OR}=1.67,95 \% \mathrm{Cl} 1.25-2.25$; Metwally et al. 2008).

Obese women may have reduced fecundity due to psychosocial and sociobiological factors. Prolonged time to conception could in part be secondary to a comparative reduction in sexual frequency. It has been demonstrated that obese people do not have sexual intercourse as frequently as thinner people, even if they have a co-habiting partner (Brody 2004). It was suggested that the decreased sex drive in the obese women may be derived from decreased dopamine activity and increased serotonin levels in the brain secondary to overeating. Additionally, chronic fat or sugar consumption could have psychopharmacological effects, relabelling sexual desire as a cue to eat (Brody 2004). Obese women are more likely to experience sexual dysfunction (Trischitta 2003). If obese women experience subfecundity due to pathophysiological factors, such sociobiological factors that contribute to a decline in coital frequency only serve to prolong the time to conception in this group of women.

\section{Obesity: its effect upon the embryo, uterus and ovaries}

The effect that obesity exerts upon fecundity can be categorised as hormonal, ovulatory/ovarian and endometrial. These will be discussed in turn below.

\section{Obesity and its effect on regulatory hormones}

A complex hormonal milieu works in balance to control the menstrual cycle, ovulation and development of the endometrium. Obesity has been demonstrated to perturb this balance via several direct and indirect mechanisms. Adipose tissue has been shown to disturb sex hormone secretion and bioavailability. Indirectly, obesity exerts its effect via leptin, insulin and the adipokines. Each will be considered below.

\section{Sex steroids}

Adipose tissue is an important site of steroid production and metabolism, conversion of androgens to oestrogens (aromatase activity), oestradiol $\left(\mathrm{OE}_{2}\right)$ to oestrone and dihydroepiandrosterone to androstenediol (17ß-hydroxysteroid dehydrogenase activity; Norman \& Clark 1998). Additionally, adipose tissue is implicated in the control of the bioavailability through effects upon transport proteins and the sequestration of lipid-soluble steroid hormones in adipose tissue (Pasquali \& Gambineri 2006), leading to an inflated steroid pool in obese women when compared with normal-weight controls (Gambineri et al. 2002) and altered delivery of androgens and oestrogens to their target organs. Serum concentration of sex hormone-binding globulin (SHBG) is lower in obese women. Serum SHBG concentration is increased by oestrogens, iodothyronines and $\mathrm{GH}$; and decreased by insulin and androgens (von Schoultz \& Carlstrom 1989). The net balance of regulatory disturbance in obesity leads to a reduction in the level of SHBG. Distribution of body fat has a significant impact upon serum SHBG concentration, with central obesity inducing a more profound reduction in serum concentrations. Serum SHBG is inversely proportional to WHR. Indeed, age- and weight-matched controls with peripheral obesity have comparatively higher serum SHBG concentrations than their centripetally obese counterparts (Pasquali \& Casimirri 1993, Pasquali \& Gambineri 2006). Elevated circulating levels of insulin are found in central obesity leading to a reduction in hepatic synthesis of SHBG (Norman \& Clark 1998). A reduction in SHBG leads to elevated circulating free sex steroids such as testosterone, dihydrotestosterone and androstenediol, which leads to an increase in metabolic clearance of these hormones. There is, however, a compensatory increase in androgen synthesis, which creates a condition of relative functional hyperandrogenism. This is especially pronounced in those with central obesity. Indeed, it has been demonstrated that a reduction in visceral obesity is associated with a concomitant elevation in SHBG concentration and reduction in androgenicity (Leenen et al. 1994). This relative hyperandrogenaemia seen in obese women may have a pathophysiological effect upon ovarian function and contribute towards menstrual disturbance and oligo-anovulation.

\section{$L H$}

Hypersecretion of $\mathrm{LH}$ and an increased $\mathrm{LH}: \mathrm{FSH}$ ratio have been demonstrated to be unfavourable for folliculogenesis; both conditions can be observed in obese infertile patients (Yen et al. 1970, Balen 1993, Butzow et al. 2000). Weight loss has been demonstrated to lead to a reduction in LH levels in patients with PCOS but does not alter the pulsatility of LH secretion (Guzick et al. 1994, Huber-Buchholz et al. 1999, Butzow et al. 2000). However, in lean women with PCOS, elevated $\mathrm{LH}$ is a major pathophysiological feature that leads to hyperandrogenaemia. In contrast, in obese women with PCOS, it is elevated insulin resistance that is the main driver of hyperandrogenism and its consequent effect upon follicular development and ovulation (Balen 2008, Balen et al. 2009).

\section{Insulin}

The ovary is a target organ for insulin; it acts via the insulin receptor and via the insulin-like growth factor 1 (IGF1) receptor. These receptors have been detected in 
granulosa, theca and ovarian stromal tissue in humans. Insulin stimulates ovarian steroidogenesis in theca and granulosa cells, and enhances the stimulatory effect of LH through LH receptor upregulation (Poretsky et al. 1999). Insulin also acts at the level of the pituitary, where it may enhance the sensitivity of the gonadotroph cells to the action of GNRH, further enhancing the stimulation of ovarian steroidogenesis (Poretsky et al. 1999). Further to this, insulin modulates the bioavailability of the sex steroids via inhibition of hepatic SHBG synthesis, and also inhibits hepatic and ovarian synthesis of IGF binding protein 1 (IGFBP1; Pasquali \& Gambineri 2006). Obesity, especially central obesity, induces a state of hyperinsulinaemia and insulin resistance. Obesity-mediated insulin resistance has been related to free fatty acids, leptin and tumour necrosis factor- $\alpha$ (TNF) via modulation of receptor-mediated signalling (Matthaei et al. 2000).

In response to systemic insulin resistance, there is a compensatory increase in insulin secretion. The altered insulin metabolism (insulin resistance and hyperinsulinaemia) leads to reduced SHBG, hyperandrogenaemia and perturbation to the functionality of the IGF system, thereby increasing the likelihood of menstrual and ovulatory disturbance in obese women. Indeed, as proof of concept, weight loss of $5 \%$ or more in obese subjects has been demonstrated to favourably change insulin (decrease), IGF (decrease), SHBG (increase) and menstrual cyclicity in women with PCOS (Kiddy et al. 1989, 1992, Pettigrew \& Hamilton-Fairley 1997, Butzow et al. 2000). Similarly, it has been demonstrated in obese women who lose weight and subsequently become ovulatory that weight loss is associated with a reduction in insulin resistance and central adiposity (Clark et al. 1995).

\section{Leptin}

Leptin is a $16 \mathrm{kDa}$ messenger protein secreted by adipocytes, a product of the $\angle E P(O B)$ gene. Its secretion is pulsatile, $\sim 32$ pulses per $24 \mathrm{~h}$ (Licinio et al. 1997), secretion increasing with food intake and decreasing during starvation. Leptin is a key signalling protein, relaying the magnitude of the peripheral energy stores to the brain (hypothalamus), and it has metabolic and reproductive functions (Norman \& Clark 1998, Messinis \& Milingos 1999, Pasquali \& Gambineri 2006). In the periphery, leptin has a role in fat metabolism and an effect upon glucose metabolism through an antagonistic relationship with insulin and reduced pancreatic secretion. Centrally, leptin signals body energy stores. Acting upon the hypothalamus, leptin induces a reduction in appetite and increase in energy expenditure (Messinis \& Milingos 1999). Leptin has a regulatory role in reproductive function; it has stimulatory effects on the HPO axis at normal serum concentrations but can have inhibitory effects upon folliculogenesis and its control when levels are elevated, such as that seen during obesity (Tamer Erel \& Senturk 2009). See Table 1 for a summary of the observed actions of leptin upon the reproductive system in obesity.

Leptin exerts an effect upon the HPO axis at central and gonadal levels. Some investigators have found serum leptin concentrations to vary subtly during the menstrual cycle, with a subtle rise during the follicular phase and peaking coincident with the LH surge and then luteal phase (Brannian \& Hansen 2002). Leptin receptors have been demonstrated in the hypothalamus and pituitary, and leptin has been implicated in the control of gonadotrophin secretion (Moschos et al. 2002, Pasquali \& Gambineri 2006). Indeed, the obese $\mathrm{Ob} / \mathrm{Ob}$ mice, which are genetically leptin deficient, display infertility and hypogonadism. Administration of recombinant leptin restores the hormonal disturbance and fertility (Chehab 1996). In humans, leptin plays an important regulatory role on the HPO axis and pubertal development; young women with congenital leptin deficiency or leptin receptor mutations do not undergo puberty, and administration of leptin can induce pubertal development (Clement et al. 1998, Farooqi et al. 1999).

Leptin also has activity at an ovarian level, and the leptin receptor and leptin receptor mRNA expression have also been demonstrated in rodent and human theca cells, granulosa cells, oocytes, endometrial cells and pre-implantation embryos (Cioffi et al. 1997, Karlsson et al. 1997, Zamorano et al. 1997, Agarwal et al. 1999, Cervero et al. 2005). In vitro, leptin has been observed to affect ovarian steroidogenesis. Leptin exerts a dosedependent inhibition of $\mathrm{OE}_{2}$ synthesis in response to stimulation by FSH and IGF1 in cultured granulosa cells, and this may suggest a paracrine role for leptin (Zachow \& Magoffin 1997, Brannian \& Hansen 2002). Leptin has also been shown to suppress IGF augmentation of $\mathrm{LH}$-stimulated androstenedione synthesis in theca cells (Agarwal et al. 1999). Additionally in rats, leptin at high concentration has been observed to interfere with normal follicular development, the development of a dominant follicle, oocyte maturation and as such ovulation (Duggal et al. 2000).

Leptin may also affect folliculogenesis by regulation of perifollicular blood flow, and leptin receptors have been demonstrated on human endothelial cells. In vitro studies have shown that leptin has a stimulatory effect

Table 1 Putative reproductive effects of leptin in obesity.

\section{Putative effects of leptin in obesity}

Dysregulation of GNRH secretion ${ }^{\mathrm{a}}$

Altered ovarian steroidogenesis ${ }^{b}$

Dysregulation of folliculogenesis ${ }^{\mathrm{c}}$

Dysregulation of perifollicular blood flow ${ }^{\mathrm{d}}$

${ }^{a}$ Clement et al. (1998), Farooqi et al. (1999) and Moschos et al. (2002).

bachow \& Magoffin (1997), Agarwal et al. (1999) and Swain et al.

(2004). 'Duggal et al. (2000). "Van Blerkom et al. (1997) and

Cao et al. (2001). 
upon endothelial cell proliferation and angiogenesis (Brannian \& Hansen 2002). Leptin has a synergistic angiogenic action with fibroblast growth factor- 2 and vascular endothelial growth factor. In mice, leptin has been observed to promote vascular permeability (Cao et al. 2001). Elevated leptin concentrations have been shown to progressively promote reactive oxygen species formation and oxidative damage in human endothelial cells (Bouloumie et al. 1999). High follicular fluid leptin concentrations have been correlated with a reduction in intrafollicular oxygen concentration in women undergoing IVF (Barroso et al. 1999). Localised action of leptin on the perifollicular vasculature could therefore interfere with delivery of oxygen and regulatory substances to the follicle and as such impair oocyte maturation (Van Blerkom et al. 1997, Brannian \& Hansen 2002). Mouse follicles cultured in vitro exposed to high concentrations of leptin increase follicular steroidogenesis but reduce oocyte maturation to metaphase II (Swain et al. 2004). In a study of follicular fluid leptin concentration and assisted reproductive technology (ART) outcome, it was observed that follicular fluid leptin concentration was significantly lower in women who conceived within three cycles of IVF or gamete intrafallopian transfer (GIFT) when compared with age- and weight-matched controls (Mantzoros et al. 1997). Leptin may also exert an effect on endometrial development, and leptin receptor mRNA has been detected by RT-PCR in human endometrial tissue (Alfer et al. 2000). Leptin and its receptor have been observed in secretory endometrium, in which they may have a role in regulation of embryo implantation and endometrial receptivity (Castellucci et al. 2000, Gonzalez et al. 2000, Kawamura et al. 2003). As such, perturbations to the leptin system as seen in obesity may disturb endometrial receptivity and implantation leading to impaired fecundity.

Women with PCOS have been observed to have elevated serum leptin concentrations in comparison to weight-matched controls (Brzechffa et al. 1996, Vicennati et al. 1998, El Orabi et al. 1999, Messinis \& Milingos 1999, Brannian \& Hansen 2002). However, several contradictory studies did not demonstrate any significant differences in the serum leptin levels in women with PCOS when compared with age- and weight-matched controls, but the number of subjects in some of these studies was low, as such limiting the interpretation of the conclusions made (Chapman et al. 1997, Laughlin et al. 1997, Mantzoros et al. 1997, Micic et al. 1997, Rouru et al. 1997, Gennarelli et al. 1998). Women with PCOS may exhibit altered leptin sensitivity of the hypothalamic neuropeptide $\mathrm{Y}$ (NPY) neurons to leptin inhibition, and higher plasma NPY levels have been observed in women with PCOS compared to nonPCOS controls; this may perturb GNRH secretion (Baranowska et al. 1999, Messinis \& Milingos 1999, Brannian \& Hansen 2002). Women with a normal menstrual cycle have been observed to exhibit co-pulsatility of leptin and LH secretion, and impaired pulse synchronicity has been reported in women with PCOS (Sir-Petermann et al. 1999, Brannian \& Hansen 2002). It has been suggested that the perturbation of leptin levels and sensitivity seen in PCOS may be linked to insulin resistance, although some controversy surrounds this. Indeed, it has been demonstrated that treatment of women with PCOS with insulin-sensitising agents induces a reduction in serum leptin levels (Krassas et al. 1998, Morin-Papunen et al. 1998, Pasquali et al. 2000, Kowalska et al. 2001). However, contradictory reports exist which do not demonstrate changes in leptin concentration following administration of insulin sensitisers (Mantzoros et al. 1997). Nevertheless, despite the controversy, it is tempting to speculate that if women with PCOS have tendency towards perturbations in the leptin system, then obese women with PCOS would be particularly prone to its detrimental effect upon the HPO axis leading oligo-anovulation.

Weight loss following a low-calorie diet leads to a reduction in circulating leptin and leptin mRNA expression in obese women with and without PCOS (Maffei et al. 1995, Messinis \& Milingos 1999, Stamets et al. 2004, Gosman et al. 2006). In one study, a 10\% reduction in body weight was found to lead to $53 \%$ reduction in serum leptin concentration (Considine et al. 1996). Bariatric surgery results in dramatically reduced serum leptin concentration, and the reduction in leptin has even been demonstrated to precede the weight loss (Faraj et al. 2003, Rubino et al. 2004). One might speculate that weight loss would improve reproductive potential in part by reducing circulating leptin concentration and the detrimental effect upon the HPO axis it exerts at higher concentrations.

\section{Other adipokines}

Adipocytes synthesise and release chemical messenger peptides that participate in metabolic regulation, including the action of insulin. It has been reported that some of these substances may affect reproductive function. Some of the peptides are uniquely expressed by adipose tissue, whilst others are more widely synthesised with adipose tissue contributing to the circulating pool (Gosman et al. 2006). Changes to body mass will alter the levels of such peptides. It is possible that this may have an impact upon reproduction; however, the direct effect of these adipokines upon reproductive function during obesity is difficult to prove definitively. They may also act indirectly by perturbing other regulatory systems. The relative importance of individual adipokines in reproduction is not clear, and their proposed actions are emerging with more work required to fully elucidate their role in obesity-related subfertility. Many of the reported effects have been demonstrated in rodent models, and the effects in humans require 
further evaluation. Individual adipokines and their reported effects in obesity are discussed below and summarised in Table 2.

Adiponectin is a protein secreted by the adipocytes, but serum levels drop in obesity and in insulin resistance (Gosman et al. 2006). Levels increase following weight loss and bariatric surgery (Yang et al. 2001, Gosman et al. 2006). Adiponectin has been implicated in the regulation of insulin sensitivity, serum concentrations being inversely related to insulin resistance (The ESHRE Capri Workshop Group 2006). It has been speculated that in obese states where circulating levels are lower, there would be a reduction in insulin sensitivity and this could lead to an effect upon the control of ovulation. Adiponectin has been detected within the ovary, in follicular fluid, the oocyte, the corpus luteum, theca cells, and it is weakly expressed in granulosa cells (Pierre et al. 2009). The direct effect of adiponectin in human ovarian function remains unclear; in animal models, adiponectin has been observed to influence follicular remodelling and folliculogenesis and to modulate sex steroid secretion via activation of its own receptor (adiponectin R1 and R2) and via modulation of the insulin/IGF system (Ledoux et al. 2006, Chabrolle et al. 2007, 2009, Campos et al. 2008, Pierre et al. 2009). Women with PCOS appear to have lower levels of adiponectin than non-PCO controls, and obese anovulatory women with PCOS have lower levels still, although this is not a consistent finding in the literature (Carmina et al. 2005, 2009, Toulis et al. 2009). It has been proposed that hypoadiponectinaemia in patients with PCOS or women with central obesity may contribute to worsening insulin resistance and its negative effect upon normal folliculogenesis (Escobar-Morreale et al. 2006).

Interleukin-6 (IL6) is an inflammatory mediator; approximately one-third of circulating levels are derived from adipocytes. Serum concentration increases in obesity and falls with weight loss (including bariatric surgery). Increased IL6 has been associated with a reduction in insulin sensitivity; reports suggest that IL6 has a detrimental effect upon fertility (Gosman et al. 2006). Some investigators have found that in rats, IL6 may act centrally to inhibit LH secretion (Rivier \& Vale 1990); other investigators have not replicated such an effect (Watanobe \& Hayakawa 2003). Suppressive activity of IL6 in the ovaries of rats and humans has been demonstrated. IL6 has been observed to prevent LH-triggered ovulation, inhibited LH-/FSH-induced oestrogen synthesis and suppress aromatase activity within granulosa cells (Deura et al. 2005, Gosman et al. 2006). Women with PCOS have been observed to have elevated serum and follicular IL6 when compared with non-PCOS controls whilst undergoing IVF (Amato et al. 2003). IL6, in the high levels seen in obese women, may impair fertility through interference with the HPO axis and impairment of endometrial development due to altered oestrogen secretion.

Plasminogen activator inhibitor (PAl) type- 1 primarily regulates fibrinolytic activity in the blood. Circulating PAI1 is largely produced by white and visceral fat. PAI1 increases in obesity and has been correlated with development of the metabolic syndrome (Gosman et al. 2006). PAI1 has been associated with miscarriage in women with PCOS (Glueck et al. 1999, 2003). Plasma PAl1 has been observed to reduce after a low-calorie

Table 2 Observed alterations and reproductive-endocrine effects of the adipokines in obesity.

\begin{tabular}{|c|c|c|}
\hline Adipokine & Change in obesity & Proposed effects upon reproductive-endocrine targets \\
\hline Adiponectin $^{\mathrm{a}}$ & Reduce & $\begin{array}{l}\text { Increased insulin resistance } \\
\text { Interference with folliculogenesis } \\
\text { Modulation of sex steroid secretion } \\
\text { Proportionally lower levels in obese PCOS women }\end{array}$ \\
\hline Interleukin- $6^{b}$ & Increase & $\begin{array}{l}\text { Increased insulin resistance } \\
\text { Impaired LH secretion } \\
\text { Impaired response to LH } \\
\text { Impaired oestrogen secretion }\end{array}$ \\
\hline Plasminogen activator inhibitor type- $1^{\mathrm{C}}$ & Increase & $\begin{array}{l}\text { Increased PAI1 directly correlate with } \\
\text { development of metabolic syndrome } \\
\text { Increased miscarriage risk }\end{array}$ \\
\hline Tumour necrosis factor- $\alpha^{d}$ & Increase & $\begin{array}{l}\text { Reduced insulin sensitivity } \\
\text { Inhibition of gonadotrophin secretion } \\
\text { Impaired steroidogenesis } \\
\text { Induces corpus luteum regression } \\
\text { Impaired endometrial development } \\
\text { Effects upon other adipokines } \\
\text { Increased leptin } \\
\text { Increased PAI1 } \\
\text { Reduced adiponectin }\end{array}$ \\
\hline
\end{tabular}

${ }^{a}$ Carmina et al. (2005, 2009), Ledoux et al. (2006), Chabrolle et al. (2007, 2009), Pierre et al. (2009) and Toulis et al. (2009). ${ }^{b}$ Rivier \& Vale (1990), Watanobe \& Hayakawa (2003) and Deura et al. (2005). ' ${ }^{\circ}$ Glueck et al. (1999, 2003). ' Rivier \& Vale (1990), Bruun et al. (2002, 2003) and Watanobe \& Hayakawa (2003). 
diet and after bariatric surgery. It is possible that PAI1 in high levels such as those seen on obese women impairs fertility through an adverse effect upon implantation and maintenance of the pregnancy (Gosman et al. 2006).

TNF is synthesised by adipocytes and other cells in the tissue matrix (Gosman et al. 2006). Circulating levels of TNF correlate with $\mathrm{BMI}$ and also increase in hyperinsulinaemic states (Bruun et al. 2002, 2003). TNF from adipocytes largely exerts local paracrine effects, but circulating TNF has been observed to affect insulin sensitivity (Gosman et al. 2006). TNF has been observed to affect several areas of the reproductive axis: inhibition of gonadotrophin secretion, ovulation, steroidogenesis, corpus luteum regression and endometrial development (Rivier \& Vale 1990, Terranova \& Rice 1997, Wood \& Strauss 2002, Watanobe \& Hayakawa 2003, Gosman et al. 2006). Disturbance of TNF in obesity may impair control of fertility at multiple levels.

\section{Obesity and the oocyte}

Several groups have observed that being overweight or obese can have a detrimental effect upon oocyte quality and/or maturity; these studies varied, however, in terms of definition of oocyte quality and obesity (Wittemer et al. 2000, Carrell et al. 2001, Dokras et al. 2006, Esinler et al. 2008). In a study done to assess the impact of isolated obesity upon ICSI outcome, it was observed that obese women (BMI $>30 \mathrm{~kg} / \mathrm{m}^{2}$ ) required higher total doses of gonadotrophin stimulation, despite significantly fewer oocyte-cumulus complexes and metaphase II oocytes being retrieved, suggesting that obesity may independently be a risk factor for impaired oocyte maturation (Esinler et al. 2008). In a retrospective analysis of IVF outcome in 1293 women, it was observed that the obese women despite developing the same number of follicles as normal-weight controls had significantly fewer oocytes retrieved and significantly fewer metaphase II oocytes (Dokras et al. 2006). Similarly, in a retrospective analysis of IVF outcome in relation to $\mathrm{BMI}$, it was observed that overweight women (BMI $>25 \mathrm{~kg} / \mathrm{m}^{2}$ ) had relatively fewer metaphase II oocytes collected (Wittemer et al. 2000). Likewise, a further prospective analysis of outcome of IVF demonstrated a reduction in oocyte number and a reduction in the number of mature (metaphase II) oocytes retrieved in the obese women (BMI $\left.>30 \mathrm{~kg} / \mathrm{m}^{2}\right)$ - these reductions, however, were not statistically significant. In this study, it was observed that intrafollicular human chorionic gonadotrophin (hCG) concentration was significantly lower in obese women. It was suggested that a reduction in delivery of hCG to the follicles may be related to the impaired oocyte maturation (metaphase II) seen in obese women (Carrell et al. 2001). However, a recent large retrospective analysis of 6500 IVF cycles has failed to demonstrate a weight-related reduction in the number and maturity of oocytes retrieved. This study did, however, observe reduced implantation, pregnancy and live birth in the obese women. This study was significantly larger than the other cited publications; however, the background demographics were similar. A significant proportion of the women in Bellver et al. (2010) followed the short GNRH antagonist protocol, whereas all of those in the other cited studies followed the long GNRH agonist protocol. Whether this had any effect upon the findings in terms of oocyte quality is unclear.

A surrogate marker of oocyte quality in the context of IVF is fertilisation rate. In a prospective evaluation of the effect of obesity in IVF/ICSI in 162 patients, it was observed that obese women had a $45 \%$ lower fertilisation rate when compared with normal-weight controls (van Swieten et al. 2005). A prospective cohort study of 50 overweight (BMI $>26 \mathrm{~kg} / \mathrm{m}^{2}$ ) and 50 normal controls (BMI $18-25 \mathrm{~kg} / \mathrm{m}^{2}$ ) observed that fertilisation rate was significantly reduced in overweight women (46.2 vs $61.3 \%, P<0.05$; Salha et al. 2001). A more recent report has observed a more modest but statistically significant reduction in fertilisation rate in overweight women (BMI $>24 \mathrm{~kg} / \mathrm{m}^{2}$ ) compared with normal women (BMI $\left.<24 \mathrm{~kg} / \mathrm{m}^{2}\right), 51.7$ vs $58.9 \%$ (Matalliotakis et al. 2008). However, other reports have not observed a weight-related reduction in fertilisation rate (Wittemer et al. 2000, Fedorcsak et al. 2004, Dokras et al. 2006, Esinler et al. 2008, Bellver et al. 2010). The heterogeneity of the studies above may be a reflection of differences in study design and variation in the definition of obesity. It highlights the necessity for prospective trials using the same regimes and definition of obesity.

Some authors suggest that the increased rates of miscarriage and very early pregnancy loss seen in obese women can be attributed to a reduction in oocyte quality (Fedorcsak et al. 2004, Lashen et al. 2004, Robker 2008). Impaired oocyte developmental competence may impair the developmental potential of the embryo, which may lead to an impaired implantation rate and subsequent abnormal implantation/trophoblastic invasion (Robker 2008). This has been observed in obese mice. Oocytes from obese mice and controls were fertilised and cultured in vitro. Oocytes from the obese mice displayed slower embryo development maintained through to the blastocyst stage. Additionally, there were perturbations to the distribution of blastomeres (Minge et al. 2008). This study also observed the effect of insulinsensitising agents upon oocyte development. Rosiglitazone, a peroxisome proliferator-activated receptor- $\gamma$ (PPARG) agonist, was observed to improve oocyte development potential in the obese mice (Minge et al. 2008), suggesting that insulin resistance and PPARG regulation may be involved in the pathogenic effect of obesity upon oocyte development. 


\section{Obesity and the endometrium}

Several studies have attempted to define the effect of obesity on the endometrium. However, contradictory findings have been reported, and importantly studies varied in design (Cano et al. 2001, Bellver et al. 2003, 2007, Wattanakumtornkul et al. 2003, Styne-Gross et al. 2005). It has been proposed that the oocyte donation model provides the best human model for discriminating between the effects of obesity upon the oocyte/embryo and the endometrium and uterine receptivity (Bellver et al. 2007). The validity of this model has been questioned by some authors, who have suggested that crucial differences may exist between non-obese and obese women who require oocyte donation and those who do not, thereby creating a bias in the results using this model (Howards \& Cooney 2008). A retrospective study of 2656 oocyte donation cycles with good quality embryos observed the effect of obesity in the recipient. Recipients were divided into groups: $\mathrm{BMI}<20$, BMI 20-24.9, BMI 25-29.9 and BMI $>30 \mathrm{~kg} / \mathrm{m}^{2}$. Linear regression analysis demonstrated a negative trend in pregnancy rates with increasing $\mathrm{BMI}$, with statistically significantly lower ongoing pregnancy rates in the overweight $(38.9 \%)$ and obese $(36.1 \%)$ women compared to normal controls (45.2\%). However, implantation rates were similar in all groups suggesting an increased pregnancy loss rate in the obese women (Bellver et al. 2007). This large study addressed the methodological issues criticised in a previous study by the same group with the same findings by increasing sample size and including only one recipient cycle per patient (Bellver et al. 2003). A case-control study of 139 women undergoing 180 cycles of IVF (using own gametes) observed that women with a BMl $>25 \mathrm{~kg} / \mathrm{m}^{2}$ had reduced implantation and pregnancy rates with elevated rates of miscarriage (Loveland et al. 2001). In contrast, a smaller and underpowered study of 97 oocyte recipients investigated the effect of obesity upon pregnancy and implantation. The area under the receiver operating characteristic (ROC) curve was $0.51(95 \% \mathrm{Cl}$ 0.41-0.62), suggesting no relationship between $\mathrm{BMI}$ and implantation rate. Likewise, there were no significant differences observed in pregnancy rates between the BMI strata (Wattanakumtornkul et al. 2003). Styne-Gross et al. (2005) investigated 536 first cycle donor oocyte recipients undergoing embryo replacement. No significant differences were observed in implantation or pregnancy rate; again ROC curve analysis observed no correlation between $\mathrm{BMI}$ and pregnancy.

The histopathological and molecular effect of obesity upon the endometrium remains to be fully elucidated. Leukaemia inhibitory factor (LIF) has been implicated in the regulation of implantation (Senturk \& Arici 1998). In an analysis of women with unexplained recurrent pregnancy loss, a subgroup had endometrial glandular LIF examined. A significant negative correlation between glandular LIF and BMI was observed. However, no differences in endometrial morphology or steroid receptor concentration were observed in obese women (Metwally et al. 2007 b). It has also been suggested that the state of relative hyperoestrogenaemia seen in the obese women may have a detrimental effect upon endometrial receptivity (Tamer Erel \& Senturk 2009). Visceral obesity has been observed to alter insulin resistance, inflammatory mediators, coagulation and fibrinolysis. Obesity is associated with insulin resistance and hyperinsulinaemia, and elevated insulin levels have been associated with a reduction in glycodelin and a reduction in IGFBP1. Low levels of glycodelin have been associated with recurrent pregnancy loss. IGFBP1 has been observed to facilitate adhesion at the maternalfoetal interface. Therefore, perturbation of such molecules may contribute to reduced fertility at an endometrial level (Carrington et al. 2005, Levens \& Skarulis 2008). Obese women have been observed to have elevated levels of acute phase proteins and pro-inflammatory cytokines (including IL6, PAI1 and TNF); these inflammatory markers are thought to exert a negative effect upon implantation and early embryonic development (Gosman et al. 2006, Esinler et al. 2008, Levens \& Skarulis 2008). Therefore, one could speculate that the higher levels seen in the obese women might impart a negative influence upon implantation and subsequent pregnancy. Reduced expression of the glucose transporter 4 (SLC2A4, GLUT4) has been associated with the development of insulin resistance in muscle and adipose tissue in obese women and particularly those with PCOS (Rosenbaum et al. 1993, Mioni et al. 2004, Mozzanega et al. 2004). Reduced endometrial expression of SLC2A4 and SLC2A4 mRNA has been demonstrated in obese women with PCOS compared with lean PCOS and lean controls (Mioni et al. 2004). This may reflect insulin resistance at an endometrial level in obese PCOS women. Since insulin has also been implicated in the regulation of endometrial development, metabolism and receptivity, one could envisage that the development of endometrial insulin resistance would affect fertility (Hackl 1973, Straus 1984, Strowitzki et al. 1993).

The effect of obesity upon implantation rate has been inconsistently reported. Some authors have identified a reduction in implantation rates among the obese women (Loveland et al. 2001, Nichols et al. 2003, Bellver et al. 2010), whereas others have not demonstrated a weightrelated reduction (Fedorcsak et al. 2004, Dechaud et al. 2006, Dokras et al. 2006). An unfavourable intrauterine milieu and impaired endometrial receptivity are plausible loci for the effect of obesity upon subfecundity; however, the evidence is inconsistent and obese women tend to suffer non-recurrent spontaneous pregnancy loss (Lashen et al. 2004, Bellver et al. 2006). This suggests that whilst the endometrium may play a part, oocyte quality is likely to be the more influential factor. 


\section{Obesity and the embryo}

Since early embryonic development is largely driven by the oocyte, one might expect that if obesity affects oocyte development, then it would affect embryonic development also. Inconsistent findings have been reported with respect to the effect of obesity upon embryo quality (Carrell et al. 2001, Fedorcsak et al. 2004, Spandorfer et al. 2004, Dechaud et al. 2006, Metwally et al. 2007a). In a prospective study of 247 women undergoing IVF, it was observed that obese (BMI $>30 \mathrm{~kg} / \mathrm{m}^{2}$ ) women had significantly poorer quality embryos compared with women with BMI $20-30 \mathrm{~kg} / \mathrm{m}^{2}$ (Carrell et al. 2001). However, other researchers were unable to demonstrate significant differences in quality of the transferred embryos between the BMI strata (Fedorcsak et al. 2004, Spandorfer et al. 2004, Dechaud et al. 2006). Whilst the quality of the transferred embryos may not be significantly different in obese women, some authors have reported a reduction in the overall quality of the embryos created in an IVF cycle (Metwally et al. 2007a, Esinler et al. 2008). In a study of the effect of isolated obesity upon ICSI outcome, embryo quality was similar in all BMI strata. However, significantly fewer overweight $(15.0 \%)$ and obese $(10.7 \%)$ women had cryopreservation of surplus embryos when compared to women with a normal BMI (22.7\%; Esinler et al. 2008). A retrospective analysis of 426 IVF/ICSI cycles observed that in young women $(<35$ years), obesity lead to a significant reduction in mean embryo quality, significant reduction in cryopreservation and a significant reduction in embryo utilisation. Interestingly, in older patients (>35 years), the above parameters were similar across the BMI strata (Metwally et al. 2007a). In contrast, a retrospective analysis of 6500 IVF cycles failed to demonstrate a difference in embryo quality and embryo cryopreservation across the BMI strata despite observing poorer outcomes in the obese women (Bellver et al. 2010). The series described by Bellver et al. is significant due to its size, and approaches a sample size similar to the combined data used in a recent meta-analysis (Maheshwari et al. 2007). By and large, the findings are similar, but some of the findings are incongruous with the meta-analysis such as finding no difference in oocyte and embryo quality or fertilisation rate; it would therefore be important to repeat the meta-analysis including this study. It must be recognised, however, that owing to the significant heterogeneity of the single centre studies included, the reliability of meta-analysis becomes less robust. Clearly, large multi-centre prospective trials are required to resolve this matter (see also section 'Obesity and assisted conception').

A relative gonadotrophin resistance is seen in obese women, as such obese women require a higher total dose of gonadotrophin when undergoing ovarian stimulation. It has been suggested that the higher doses of gonadotrophin may lead to impaired oocyte quality and embryo quality, leading to impaired embryonic development and implantation potential (Tamer Erel \& Senturk 2009).

\section{Obesity and PCOS}

Women with PCOS are commonly overweight or obese (38-66\%), although this does not form part of the diagnostic criteria for the disorder (Balen et al. 1995, Azziz et al. 2004, Norman et al. 2007). Obesity does, however, have a profound effect upon the expression of the syndrome and the symptoms which a woman experiences; obese women with PCOS have a more severe phenotype. In a series of 1741 British women with PCOS, it was observed that $70 \%$ had menstrual cycle disturbance; obese women with PCOS had a higher prevalence $(78 \%)$ of disturbed menstrual cyclicity (Balen et al. 1995). Similar results were demonstrated in a smaller case series of 263 women with PCOS; obese PCOS women had an $88 \%$ chance of menstrual cycle disturbance, whereas non-obese women had a $72 \%$ chance (Kiddy et al. 1992). The mechanisms by which obesity influences the pathophysiology and clinical expression of PCOS are complex and yet to be fully elucidated; however, the mechanisms are likely to be similar to those in obese non-PCOS women, and since women with PCOS have a background of insulin resistance and hyperandrogenism, the deleterious effects of obesity upon reproduction will tend to be exaggerated (see Table 3). Central obesity is particularly associated with reproductive disturbance in PCOS leading to chronic oligo-/anovulation; a proposed mechanism includes hyperandrogenism secondary to an insulinmediated overstimulation of ovarian steroidogenesis and decreased serum SHBG concentration (Davies 2006, Pasquali \& Gambineri 2006, Norman et al. 2007). Women with PCOS are prone to develop insulin

Table 3 Effect of obesity upon polycystic ovary syndrome (PCOS).

\section{Effect of obesity upon PCOS}

Increased androgen levels ${ }^{\mathrm{a}}$

Reduced sex hormone-binding globulin levels ${ }^{\mathrm{b}}$

Reduced menstrual cyclicity ${ }^{\mathrm{c}}$

Increased prevalence of oligo/anovulation ${ }^{\mathrm{C}}$

Increased insulin resistance ${ }^{\mathrm{d}}$

Impaired response to gonadotrophin during superovulation ${ }^{\mathrm{e}}$

Increased chance of cycle cancellation (OR 1.86, 95\% Cl 1.13-3.06)

Reduced ovulation rates (OR $0.44,95 \% \mathrm{Cl} 0.31-0.61$ )

Reduced chance of treatment success following $\mathrm{ART}^{f}$

Increased risk of miscarriage (OR 3.05, 95\% CI 1.45-6.44)

${ }^{a}$ Kiddy et al. (1992), Holte et al. (1994), Dunaif (1997) and Poretsky et al. (1999). ' Kiddy et al. (1992). 'Kiddy et al. (1992) and Balen et al. (1995). 'Dunaif (1997), Poretsky et al. (1999) and Morin-Papunen et al. (2000). ${ }^{e}$ Mulders et al. (2003). 'Hamilton-Fairley et al. (1992), Clark et al. (1995, 1998), White et al. (1996), Wang et al. (2000) and

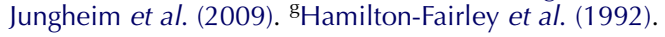


resistance; fasting and glucose-stimulated insulin concentrations are significantly higher in women with PCOS compared to those without PCOS. Obese women with PCOS are more prone to developing insulin resistance and hyperinsulinaemia, and more frequently exhibit the clinical manifestations of insulin resistance, acanthosis nigricans (Gambineri et al. 2002, Pasquali \& Gambineri 2006). In abdominal obesity, insulin resistance develops and a compensatory hyperinsulinaemia occurs; however, the ovary remains responsive to insulin. Elevated levels of insulin lead to increase steroidogenesis and excessive androgen production by the ovarian theca cells (Dunaif 1997). Elevated local ovarian androgen production leads to premature follicular atresia and consequently increases the likelihood of oligo-/anovulation (Dunaif 1997, Poretsky et al. 1999, Morin-Papunen et al. 2000, Pasquali \& Gambineri 2006, Norman et al. 2007).

Acyclic excessive production of oestrogens may exert a positive feedback regulation upon LH release and negative feedback upon FSH release, leading to a rise in ovarian androgen production (Gambineri et al. 2002, Pasquali \& Gambineri 2006). It has also been suggested that an increased tone in the opioid system seen in obese women with PCOS may, in part, favour the development of hyperinsulinaemia as $\beta$-endorphin has been observed to stimulate insulin secretion (Pasquali \& Gambineri 2006). Obesity, particularly abdominal obesity, in PCOS favours a state of hyperandrogenaemia due to significantly lower SHBG and higher circulating androgen levels. Obese women with PCOS more frequently exhibit the clinical manifestations of hyperandrogenism and menstrual cycle disturbance (Holte et al. 1994, Gambineri et al. 2002). Thus, elevated androgen levels in obese women with PCOS favour a state of oligo-/anovulation and subfertility.

Obesity in women with PCOS reduces the likelihood of natural conception and also reduces the likelihood of conception following fertility treatment (HamiltonFairley et al. 1992, Clark et al. 1995, 1998, White et al. 1996, Wang et al. 2000). Elevated BMI in women with PCOS is associated with an increased risk of miscarriage (Hamilton-Fairley et al. 1992). A recent analysis of morbidly obese (BMI $>40 \mathrm{~kg} / \mathrm{m}^{2}$ ) women with PCOS undergoing IVF at an American clinic has found a significant impairment in clinical pregnancy rate in this group. These women had lower peak $\mathrm{OE}_{2}$ concentrations, fewer oocytes collected and impaired fertilisation rates, suggesting impaired follicular response and oocyte development in the morbidly obese women (Jungheim et al. 2009).

Menstrual cyclicity and the endocrine profile improve following weight reduction, proof of concept that obesity worsens the PCOS phenotype (Franks et al. 1991, Pasquali et al. 1997, Huber-Buchholz et al. 1999, Moran \& Norman 2004, Tang et al. 2006, Norman et al. 2007). Even modest weight loss of $5-10 \%$ in obese women with PCOS has been observed to lead to improvements in hormonal profiles, menstrual cyclicity and fertility (Kiddy et al. 1992, Crosignani et al. 2003).

\section{Obesity and assisted conception}

A survey of studies reporting the effect of obesity upon ART outcome reveals inconsistent findings, although study design and definition of obesity are variable. However, the majority of the studies suggest that obesity has a deleterious effect upon ART. Obesity has been reported to affect ovarian stimulation in women undergoing treatment. Reported effects include prolonged ovarian stimulation, increased dose requirement of gonadotrophin, increased incidence of follicular asynchrony and increased cancellation rates (Mulders et al. 2003, van Swieten et al. 2005, Balen et al. 2006, Bellver et al. 2006, Maheshwari et al. 2007, Esinler et al. 2008). In a cohort study of women with PCOS undergoing ovulation induction with either clomiphene or gonadotrophins, it was observed that elevated BMI negatively affected ovulation rates. In this study, obese patients had significantly lower ovulation rates at 6 months of treatment: $79 \%$ in women with BMI of $18-24 \mathrm{~kg} / \mathrm{m}^{2}$, compared with $15.3 \%$ with BMI $30-34 \mathrm{~kg} / \mathrm{m}^{2}$ and $12 \%$ if BMI $>35 \mathrm{~kg} / \mathrm{m}^{2}$ (Al-Azemi et al. 2004). Some authors, however, have been unable to demonstrate any difference in ovarian response to stimulation in obese women (Lashen et al. 1999, Dechaud et al. 2006, Martinuzzi et al. 2008).

Follicular recruitment during ovarian stimulation requires the serum $\mathrm{FSH}$ concentration to exceed a therapeutic threshold; this threshold varies between patients, but has been observed to be higher in women with elevated BMI. Higher doses of gonadotrophin required in obese women may be related to altered pharmacodynamics, altered $\mathrm{OE}_{2}$ metabolism and decreased SHBG concentrations (Tamer Erel \& Senturk 2009). The absorption, metabolism and clearance of gonadotrophins injected s.c. have been observed to differ in obese women with PCOS (Fridstrom et al. 1997). A study of pharmacokinetics in healthy volunteers observed that there was no advantage in i.m. or s.c. injection in obese women (Steinkampf et al. 2003). Factors other than absorption and clearance of gonadotrophins may be responsible for increased dose requirement in obese women; obesity has been associated with a relative gonadotrophin resistance (Fedorcsak et al. 2001). Insulin resistance seen in obese women has been associated with a relative gonadotrophin resistance (Homburg et al. 1996, Fulghesu et al. 1997, Dale et al. 1998). A meta-analysis of patient predictors for the outcome of gonadotrophin ovulation induction confirmed a positive correlation between obesity and the amount of gonadotrophin required, and a weighted mean difference (WMD) of $771 \mathrm{IU}$ is more required in 
obese women $(95 \% \mathrm{Cl} 700-842)$. Ovulation rate was observed to be impaired in the obese women (OR 0.44, 95\% Cl 0.31-0.61; Mulders et al. 2003). As discussed above, leptin concentrations are elevated in obese women, and it has been suggested that high intrafollicular leptin concentrations are associated with relative gonadotrophin resistance during ovarian stimulation in IVF, through a postulated inhibitory effect upon FSH-stimulated steroid synthesis by granulosa cells (Zachow \& Magoffin 1997, Agarwal et al. 1999, Tamer Erel \& Senturk 2009). The elevated doses of gonadotrophin used to compensate for the relative gonadotrophin resistance induced by obesity may be deleterious, potentially leading to impairment of embryonic developmental potential and implantation (Fedorcsak et al. 2001). There is also a postulated detrimental effect upon uterine receptivity. In mice, superovulation induces abnormal embryonic development, decreased invasional capacity of blastocysts in vitro and impaired implantation rates (Ertzeid \& Storeng 1992, Ertzeid et al. 1993).

Obese women undergoing IVF/ICSI have lower live birth rates. It is thought that this is the cumulative effect of lower implantation and pregnancy rates, higher miscarriage rates and increased obstetric complications (Bellver et al. 2006). Whilst some authors have reported lower pregnancy and live birth rates in obese women undergoing assisted conception treatments (Wang et al. 2000, Carrell et al. 2001, Loveland et al. 2001, Nichols et al. 2003, Fedorcsak et al. 2004, Bellver et al. 2010), others have been unable to demonstrate reduction in success rates in obese women (Lashen et al. 1999, Wittemer et al. 2000, Dechaud et al. 2006, Martinuzzi et al. 2008, Matalliotakis et al. 2008). A retrospective analysis of outcomes in 3586 patients undergoing IVF/ICSI/GIFT observed that the cumulative chance of achieving at least one pregnancy was significantly reduced in the obese women when compared to normal controls (BMI $20-24.9 \mathrm{~kg} / \mathrm{m}^{2}$ ), obese group (BMI $30-34.9 \mathrm{~kg} / \mathrm{m}^{2}$, OR $0.73,95 \% \mathrm{Cl} 0.57-0.96$ ) and very obese group (BMI $>35 \mathrm{~kg} / \mathrm{m}^{2}$, OR $0.50,95 \% \mathrm{Cl}$ 0.32-0.77; Wang et al. 2000). In a retrospective analysis of 5019 IVF/ICSI cycles in 2660 women, it was observed that obesity (BMI $>30 \mathrm{~kg} / \mathrm{m}^{2}$ ) was associated with a significant reduction in live birth rates (OR $0.75,95 \% \mathrm{Cl}$ $0.57-0.98)$ and a significantly elevated chance of miscarriage (OR 1.68, 95\% Cl 1.13-2.51; Fedorcsak et al. 2004).

A retrospective study of 417 women undergoing their first IVF cycle observed the effect of BMI upon IVF. A high prevalence of PCOS was seen in the obese category; therefore, the authors performed subset analyses comparing the BMI strata in the PCOS and non-PCOS groups. Whilst no significant differences were observed in the non-PCOS obese groups, it was observed that obesity in women with PCOS lead to a significant reduction in implantation and ongoing pregnancy rates
(Martinuzzi et al. 2008). Additionally, an interesting finding was that obese women were significantly more likely to encounter difficulty in observing the air bubble during ultrasound-guided embryo transfer and were more likely to have blood on or in the catheter after embryo transfer, factors which have been associated with poorer success rates after embryo transfer (Martinuzzi et al. 2008). A retrospective study at a US centre observed the outcomes of IVF/ICSI in lean (BMI $\left.18.5-24.9 \mathrm{~kg} / \mathrm{m}^{2}\right)$ and obese $\left(\mathrm{BMl}>30 \mathrm{~kg} / \mathrm{m}^{2}\right.$ ) women with and without PCOS. It was observed that lean women had more favourable cycle characteristics, but there were no significant differences in terms of implantation, clinical pregnancy, miscarriage or live birth rates (McCormick et al. 2008).

The distribution of body fat is also important, central/abdominal obesity having a larger impact upon fertility. A study of 220 women undergoing IVF observed that a WHR $>0.8$ was associated with a significant reduction in pregnancy rate (OR $0.42,95 \% \mathrm{Cl} 0.2-0.9$ ). In this same study, BMI was not, however, found to correlate with IVF outcome (Wass et al. 1997). Changes in weight have been observed to influence treatment success; a unit increase of BMI has been shown to reduce the odds of a pregnancy following IVF by 0.84 and conversely weight loss improving the odds of achieving a pregnancy by a factor of 1.19 for each unit reduction in BMI (Ferlitsch et al. 2004). In a recent systematic review and meta-analysis, the effect of elevated BMI on IVF outcome was investigated. Pooled analysis demonstrated that patients with BMI $>25 \mathrm{~kg} / \mathrm{m}^{2}$ had a lower chance of pregnancy after IVF (OR 0.71, 95\% Cl 0.62-0.81). Patients with an elevated BMI required significantly more gonadotrophin for ovarian stimulation, for BMI $>25 \mathrm{~kg} / \mathrm{m}^{2}$, WMD 210.08 (95\% Cl 149.12-271.0), and for BMI >30 kg/m², WMD $361.94(95 \% \mathrm{Cl}$ 156.47-567.40). Elevated BMI was observed to increase the risk of miscarriage, $\mathrm{BMI}>25 \mathrm{~kg} / \mathrm{m}^{2}$ (OR 1.33, 95\% $\mathrm{Cl} 1.06-1.68$ ) and $\mathrm{BMI}>30 \mathrm{~kg} / \mathrm{m}^{2}$ (OR $1.53,95 \% \mathrm{Cl}$ 1.27-1.84). However, the authors stated that there was insufficient evidence to determine the effect on live birth rates, and called for more rigorous prospective work to determine the true effect of BMI (Maheshwari et al. 2007). A summary of the reported effects of obesity upon ART is given in Table 4.

\section{Fertility after weight loss}

Weight loss improves reproductive function in overweight and obese women (Clark et al. 1995, 1998, Hollmann et al. 1996, Crosignani et al. 2003, Tang et al. 2006). It is, therefore, of paramount importance that overweight and obese women attending subfertility clinics are given the necessary advice and support to achieve the necessary weight loss. The first line of approach should be through lifestyle modification with careful counselling on diet and exercise; dietary 
Table 4 Effects of obesity upon assisted reproductive technology (ART).

\section{Effects of obesity upon ART}

Impaired USS image quality due to adipose tissue ${ }^{a}$

Increased duration of stimulation

Increased total gonadotrophin dose required (WMD 361.94, 95\% Cl: 156.47, 567.40; BMI <30 vs >30) ${ }^{\text {b }}$

Increased follicular asynchrony ${ }^{\mathrm{C}}$

Increased cycle cancellation (OR 1.35, 95\% Cl: 0.99, 1.84; BMI $>30$ vs $<30)^{\text {d }}$

Poor response to superovulation ${ }^{\mathrm{e}}$

Reduced follicular hCG concentration on day of ovum pickup (inverse correlation with BMI $(r=-0.353, P<0.001))^{f}$

Relative reduction in number of cumulus-oocyte complex recovered at ovum pickup ${ }^{\mathrm{g}}$

Relative reduction in metaphase II oocytes recovered at ovum pickup ${ }^{\mathrm{h}}$

Reduced number of surplus good quality embryos available for cryopreservation ${ }^{i}$

Reduced pregnancy rates (OR 1.47, 95\% Cl: 1.20, 1.80; $\mathrm{BMI}<30 \mathrm{vs}>30)^{\mathrm{j}}$

Increased miscarriage rates $(\mathrm{OR}=1.53,95 \% \mathrm{Cl}: 1.27,1.84 ; \mathrm{BMI}>30 \text { vs }<30)^{\mathrm{k}}$

OR, odds ratio; WMD, weighted mean difference.

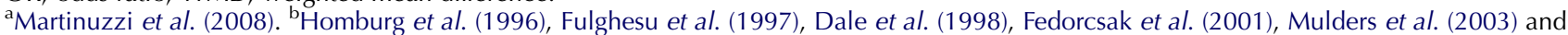
Maheshwari et al. (2007). 'Mulders et al. (2003), van Swieten et al. (2005), Balen et al. (2006), Bellver et al. (2006), Maheshwari et al. (2007) and Esinler et al. (2008). dMulders et al. (2003) and Maheshwari et al. (2007). ${ }^{\mathrm{e}} \mathrm{Al}-\mathrm{Azemi}$ et al. (2004). ${ }^{\mathrm{f}} \mathrm{Carrell}$ et al. (2001). ${ }^{\mathrm{g}}$ Maheshwari et al. (2007) and Esinler et al. (2008). 'Wittemer et al. (2000) and Dokras et al. (2006). 'Carrell et al. (2001), Metwally et al. (2007a, 2007b) and Esinler et al. (2008). 'Wang et al. (2000), Carrell et al. (2001), Loveland et al. (2001), Nichols et al. (2003), Fedorcsak et al. (2004), Maheshwari et al. (2007) and Bellver et al. (2010). kBellver et al. (2006).

education and guidance should ideally be given by a trained dietician. Overweight and obese women should be advised to follow a restricted calorie diet and to concomitantly undertake a programme of exercise containing a sufficient quantity of aerobic activity. Good evidence exists to support the use of supervised weight loss or group programmes in terms of improved weight loss, ovulatory frequency, pregnancy rates and cost efficiency per pregnancy achieved, although the provision of such services will be limited by local resources (Guzick et al. 1994, Clark et al. 1995, 1998, Hollmann et al. 1996, Tang et al. 2006, Balen \& Anderson 2007). An industry has been created out of extolling the virtues of various diets and dieting regimes; however, there is little evidence to suggest that one is particularly better than another in terms of improving reproductive potential. The most important feature for achieving weight loss is maintaining a negative energy balance. Calorie restriction, however this might be achieved, should be advised (Norman et al. 2004, Balen \& Anderson 2007). One must be careful not to promote extreme rapid dieting and acute very low calorie diets, as these have been associated with poor compliance and poor ART outcomes (Tsagareli et al. 2006). When counselling overweight and obese women regarding weight loss, it is essential to emphasise the importance of making lifestyle modifications that are sustainable and healthy. In some women, it may be appropriate to resort to weight-reducing agents where initial attempts at weight loss through diet and exercise have failed (Padwal \& Majumdar 2007). However, caution should be exercised when prescribing, and such women should be kept under careful surveillance. Orlistat, a lipase inhibitor that reduces gastrointestinal fat absorption, is largely regarded as safe to use in this context. Orlistat has been observed to improve weight loss, insulin resistance and hyperandrogenaemia in obese women with PCOS (Jayagopal et al. 2005, Panidis et al. 2008, Cho et al. 2009, Metwally et al. 2009). Any weight-reducing agent used should be stopped when pregnancy is confirmed.

Increasingly, bariatric surgery is used to treat morbid obesity in women of reproductive age who have been unable to achieve adequate weight loss through dietary modification and exercise. In the US, between 2003 and 2005, more than 50000 women aged 18-45 underwent bariatric surgery annually (Maggard et al. 2008). Bariatric surgery involves either reducing the stomach capacity (e.g. gastric band) or reducing absorption through anatomical modification and reducing capacity (e.g. Roux-en-Y gastric bypass) or reducing absorption through anatomical modification (e.g. biliopancreatic diversion). Bariatric surgery is considered when BMI $>40 \mathrm{~kg} / \mathrm{m}^{2}$ or BMI $>35 \mathrm{~kg} / \mathrm{m}^{2}$, and serious concomitant medical problems are exacerbated by obesity (NIH Conference 1991, Merhi 2007, Guelinckx et al. 2009). Rapid weight loss follows the surgery; the majority of the weight loss occurs in the first year. Pregnancy is best avoided during this time (Maggard et al. 2008).

The reproductive aberrations induced by obesity improve after bariatric surgery. Bariatric surgery can lead to improvements in menstrual cyclicity (Teitelman et al. 2006). A questionnaire study of women undergoing bariatric surgery observed oligomenorrhoea in $40 \%$ of premenopausal women presenting for bariatric surgery. After weight stabilisation, $81 \%$ of the oligomenorrhoeic women had become eumenorrhoeic. Pre-operatively, $25 \%$ of women reported infertility, after surgery of these women, all who tried to conceive were successful (Deitel et al. 1988). It is likely that the reduction in adipose tissue reverses the negative hormonal/paracrine influence over the reproductive system, restoring the fertility potential in these women. Twelve morbidly obese women with PCOS underwent bariatric surgery 


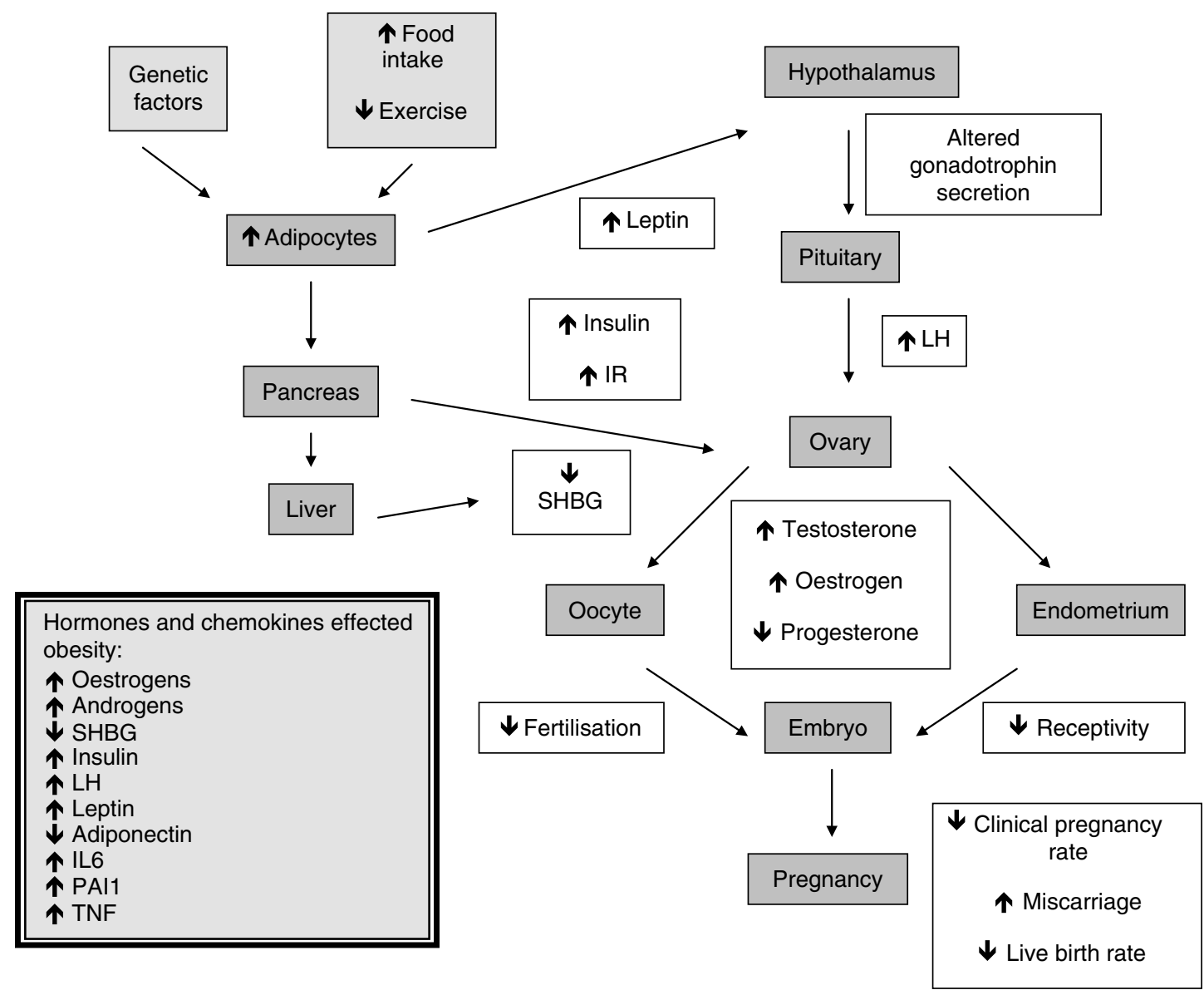

Figure 1 Summary of the reported effects of obesity upon the hypothalamic-pituitary-ovarian axis and effect upon reproductive potential. The findings in the reported literature have varied; please see the main text for a fuller account of the reported effects and how consistently they have been observed. IL6, interleukin-6; IR, insulin resistance; PAI1, plasminogen activator inhibitor type-1; SHBG, sex hormone-binding globulin; TNF, tumour necrosis factor- $\alpha$.

and were followed up in a longitudinal study. Postoperative weight loss was associated with a marked improvement in clinical and biochemical hyperandrogenism. Likewise, weight loss was associated with restoration of menstrual cyclicity. In the majority of these women, the diagnosis of PCOS could not be sustained after the weight loss due to an amelioration of symptoms (Escobar-Morreale et al. 2005). An observational study of 24 morbidly obese women with PCOS undergoing Roux-en-Y gastric bypass demonstrated improved menstrual cyclicity in all women and reduced hirsutism in half. Five conceived naturally (Eid et al. 2005), highlighting the sensitivity of the condition to changes in body weight. Other case series have observed improved natural conception rates post-operatively (Bilenka et al. 1995, Marceau et al. 2004). Interestingly, bariatric surgery may not be so beneficial for male fertility, and a case series of six previously fertile men were observed to develop secondary subfertility and azoospermia (secondary to spermatogenic arrest) following profound weight loss after a Roux-en-Y gastric bypass (di Frega et al. 2005).
When considering fertility after bariatric surgery, the obstetric impact of the surgery is paramount. The risk of obstetric complications (including gestational diabetes, macrosomia and hypertensive disorders) is reduced following operative induced weight loss when compared to morbidly obese women. However, nutritional deficiencies can occur, particularly with the malabsorptive forms of bariatric surgery or with non-compliance with supplements. Deficiencies in iron, vitamin A, vitamin $\mathrm{B}_{12}$, vitamin $\mathrm{K}$, folate and calcium can occur leading to maternal complications (e.g. anaemia) and foetal complications (e.g. congenital abnormalities, in utero growth retardation; Guelinckx et al. 2009). It is inadvisable to conceive during the period of rapid weight loss as this is most likely to result in nutritional and metabolic instabilities (Balen \& Anderson 2007, Maggard et al. 2008). Women conceiving after bariatric surgery should receive careful counselling by a dietician to reduce the risk of nutritional deficiency. Indeed, some reports of poor pregnancy outcome have occurred in patients where nutritional advice and supplementation have not been adhered to (Guelinckx et al. 2009). 


\section{Conclusions}

Obesity impairs reproductive outcome significantly. Notwithstanding its effect upon the likelihood of conceiving, it has important consequences upon the health and outcome of the ensuing pregnancy. The British Fertility Society has issued policy and practice guidelines advising clinicians to advise patients to aim for a normal BMI prior to commencing fertility treatment. Indeed, these guidelines recommend deferring any treatment until a woman's BMI $<35 \mathrm{~kg} / \mathrm{m}^{2}$, and recommending that $\mathrm{BMI}<30 \mathrm{~kg} / \mathrm{m}^{2}$ is preferable (Balen \& Anderson 2007). In summary, obesity has been observed to impair both natural and assisted conception. The exact pathophysiological mechanism through which obesity exerts its detrimental effect remains uncertain. However, animal and human data exist highlighting a negative effect at all levels of HPO axis (Fig. 1). It is likely that obesity exerts its effect upon conception and implantation through a cumulative impairment of several processes. Obesity affects ovulation, oocyte maturation, endometrial development, uterine receptivity, implantation and miscarriage. Weight loss through diet and exercise is the first-line therapy for all obese women seeking fertility treatment, and robust evidence exists to support this. Some improvement in reproductive function following weight loss surgery has been observed; however, conclusions drawn from the current literature must been interpreted with caution owing to the quality of the original data. As such, bariatric surgery cannot be recommended as a first-line fertility treatment for the obese women owing to operative morbidity and mortality and lack of clear supportive data. When considering fertility issues in obese women, one must consider the obstetric and neonatal consequences of a pregnancy. Since pregnancy is a more risky endeavour in the obese women, preconception counselling should always mandate the achievement of stable normal weight prior to natural or assisted conception. This will improve both fertility and feto-maternal health in the ensuing pregnancy.

\section{Declaration of interest}

The authors declare that there is no conflict of interest that could be perceived as prejudicing the impartiality of the research reported.

\section{Funding}

This research did not receive any specific grant from any funding agency in the public, commercial or not-for-profit sector.

\section{References}

Agarwal SK, Vogel K, Weitsman SR \& Magoffin DA 1999 Leptin antagonizes the insulin-like growth factor-I augmentation of steroidogenesis in granulosa and theca cells of the human ovary. Journal of Clinical Endocrinology and Metabolism 84 1072-1076.
Al-Azemi M, Omu FE \& Omu AE 2004 The effect of obesity on the outcome of infertility management in women with polycystic ovary syndrome. Archives of Gynecology and Obstetrics 270 205-210.

Alfer J, Muller-Schottle F, Classen-Linke I, von Rango U, Happel L, BeierHellwig K, Rath W \& Beier HM 2000 The endometrium as a novel target for leptin: differences in fertility and subfertility. Molecular Human Reproduction 6 595-601.

Amato G, Conte M, Mazziotti G, Lalli E, Vitolo G, Tucker AT, Bellastella A, Carella C \& Izzo A 2003 Serum and follicular fluid cytokines in polycystic ovary syndrome during stimulated cycles. Obstetrics and Gynecology 101 1177-1182.

Azziz R, Woods KS, Reyna R, Key TJ, Knochenhauer ES \& Yildiz BO 2004 The prevalence and features of the polycystic ovary syndrome in an unselected population. Journal of Clinical Endocrinology and Metabolism 89 2745-2749.

Balen AH 1993 Hypersecretion of luteinizing hormone and the polycystic ovary syndrome. Human Reproduction 8 (Supplement 2) 123-128.

Balen A 2008 Infertility in Practice. London: Informa Health Care.

Balen AH \& Anderson RA 2007 Impact of obesity on female reproductive health: British Fertility Society, Policy and Practice Guidelines. Human Fertility 10 195-206.

Balen AH, Conway GS, Kaltsas G, Techatrasak K, Manning PJ, West C \& Jacobs HS 1995 Polycystic ovary syndrome: the spectrum of the disorder in 1741 patients. Human Reproduction 10 2107-2111.

Balen AH, Platteau P, Andersen AN, Devroey P, Sorensen P, Helmgaard L \& Arce JC 2006 The influence of body weight on response to ovulation induction with gonadotrophins in 335 women with World Health Organization group II anovulatory infertility. British Journal of Obstetrics and Gynaecology 113 1195-1202.

Balen A, Homburg R \& Franks S 2009 Defining polycystic ovary syndrome. BMJ 338 a2968.

Baranowska B, Radzikowska M, Wasilewska-Dziubinska E, Kaplinski A, Roguski K \& Plonowski A 1999 Neuropeptide Y, leptin, galanin and insulin in women with polycystic ovary syndrome. Gynecological Endocrinology 13 344-351.

Barroso G, Barrionuevo M, Rao P, Graham L, Danforth D, Huey S, Abuhamad A \& Oehninger S 1999 Vascular endothelial growth factor, nitric oxide, and leptin follicular fluid levels correlate negatively with embryo quality in IVF patients. Fertility and Sterility 72 1024-1026.

Bellver J, Rossal LP, Bosch E, Zuniga A, Corona JT, Melendez F, Gomez E, Simon C, Remohi J \& Pellicer A 2003 Obesity and the risk of spontaneous abortion after oocyte donation. Fertility and Sterility 79 1136-1140.

Bellver J, Busso C, Pellicer A, Remohi J \& Simon C 2006 Obesity and assisted reproductive technology outcomes. Reproductive Biomedicine Online 12 562-568.

Bellver J, Melo MA, Bosch E, Serra V, Remohi J \& Pellicer A 2007 Obesity and poor reproductive outcome: the potential role of the endometrium. Fertility and Sterility 88 446-451.

Bellver J, Ayllon Y, Ferrando M, Melo M, Goyri E, Pellicer A, Remohi J \& Meseguer M 2010 Female obesity impairs in vitro fertilization outcome without affecting embryo quality. Fertility and Sterility 93 447-454.

Bilenka B, Ben-Shlomo I, Cozacov C, Gold CH \& Zohar S 1995 Fertility, miscarriage and pregnancy after vertical banded gastroplasty operation for morbid obesity. Acta Obstetricia et Gynecologica Scandinavica 74 42-44.

Bouloumie A, Marumo T, Lafontan M \& Busse R 1999 Leptin induces oxidative stress in human endothelial cells. FASEB Journal 13 1231-1238.

Brannian JD \& Hansen KA 2002 Leptin and ovarian folliculogenesis: implications for ovulation induction and ART outcomes. Seminars in Reproductive Medicine 20 103-112.

Brody S 2004 Slimness is associated with greater intercourse and lesser masturbation frequency. Journal of Sex and Marital Therapy 30 251-261.

Bruun JM, Pedersen SB, Kristensen K \& Richelsen B 2002 Opposite regulation of interleukin- 8 and tumor necrosis factor- $\alpha$ by weight loss. Obesity Research 10 499-506.

Bruun JM, Verdich C, Toubro S, Astrup A \& Richelsen B 2003 Association between measures of insulin sensitivity and circulating levels of interleukin-8, interleukin-6 and tumor necrosis factor- $\alpha$. Effect of weight loss in obese men. European Journal of Endocrinology 148 535-542. 
Brzechffa PR, Jakimiuk AJ, Agarwal SK, Weitsman SR, Buyalos RP \& Magoffin DA 1996 Serum immunoreactive leptin concentrations in women with polycystic ovary syndrome. Journal of Clinical Endocrinology and Metabolism 81 4166-4169.

Butzow TL, Lehtovirta M, Siegberg R, Hovatta O, Koistinen R, Seppala M \& Apter D 2000 The decrease in luteinizing hormone secretion in response to weight reduction is inversely related to the severity of insulin resistance in overweight women. Journal of Clinical Endocrinology and Metabolism 85 3271-3275.

Campos DB, Palin MF, Bordignon V \& Murphy BD 2008 The 'beneficial' adipokines in reproduction and fertility. International Journal of Obesity 32 223-231.

Cano F, Landeras J, Molla M, Gomez E, Ballesteros A \& Remohi J 2001 The effect of extreme of body mass on embryo implantation at oocytes donation program. Fertility and Sterility 76 S160-S161.

Cao R, Brakenhielm E, Wahlestedt C, Thyberg J \& Cao Y 2001 Leptin induces vascular permeability and synergistically stimulates angiogenesis with FGF-2 and VEGF. PNAS 98 6390-6395.

Carmina E, Orio F, Palomba S, Cascella T, Longo RA, Colao AM, Lombardi G \& Lobo RA 2005 Evidence for altered adipocyte function in polycystic ovary syndrome. European Journal of Endocrinology $\mathbf{1 5 2}$ 389-394.

Carmina E, Bucchieri S, Mansueto P, Rini G, Ferin M \& Lobo RA 2009 Circulating levels of adipose products and differences in fat distribution in the ovulatory and anovulatory phenotypes of polycystic ovary syndrome. Fertility and Sterility 91 1332-1335.

Carrell DT, Jones KP, Peterson CM, Aoki V, Emery BR \& Campbell BR 2001 Body mass index is inversely related to intrafollicular HCG concentrations, embryo quality and IVF outcome. Reproductive Biomedicine Online 3 109-111.

Carrington B, Sacks G \& Regan L 2005 Recurrent miscarriage: pathophysiology and outcome. Current Opinion in Obstetrics and Gynecology 17 591-597.

Castellucci M, De Matteis R, Meisser A, Cancello R, Monsurro V, Islami D, Sarzani R, Marzioni D, Cinti S \& Bischof P 2000 Leptin modulates extracellular matrix molecules and metalloproteinases: possible implications for trophoblast invasion. Molecular Human Reproduction 6 951-958.

Cervero A, Horcajadas JA, Dominguez F, Pellicer A \& Simon C 2005 Leptin system in embryo development and implantation: a protein in search of a function. Reproductive Biomedicine Online 10 217-223.

Chabrolle C, Tosca L \& Dupont J 2007 Regulation of adiponectin and its receptors in rat ovary by human chorionic gonadotrophin treatment and potential involvement of adiponectin in granulosa cell steroidogenesis. Reproduction 133 719-731.

Chabrolle C, Tosca L, Rame C, Lecomte P, Royere D \& Dupont J 2009 Adiponectin increases insulin-like growth factor I-induced progesterone and estradiol secretion in human granulosa cells. Fertility and Sterility 92 1988-1996.

Chapman IM, Wittert GA \& Norman RJ 1997 Circulating leptin concentrations in polycystic ovary syndrome: relation to anthropometric and metabolic parameters. Clinical Endocrinology 46 175-181.

Chehab FF 1996 A broader role for leptin. Nature Medicine 2 723-724.

Cho LW, Kilpatrick ES, Keevil BG, Coady AM \& Atkin SL 2009 Effect of metformin, orlistat and pioglitazone treatment on mean insulin resistance and its biological variability in polycystic ovary syndrome. Clinical Endocrinology 70 233-237.

Cioffi JA, Van Blerkom J, Antczak M, Shafer A, Wittmer S \& Snodgrass HR 1997 The expression of leptin and its receptors in pre-ovulatory human follicles. Molecular Human Reproduction 3 467-472.

Clark AM, Ledger W, Galletly C, Tomlinson L, Blaney F, Wang X \& Norman RJ 1995 Weight loss results in significant improvement in pregnancy and ovulation rates in anovulatory obese women. Human Reproduction 10 2705-2712.

Clark AM, Thornley B, Tomlinson L, Galletley C \& Norman RJ 1998 Weight loss in obese infertile women results in improvement in reproductive outcome for all forms of fertility treatment. Human Reproduction 13 1502-1505

Clement K, Vaisse C, Lahlou N, Cabrol S, Pelloux V, Cassuto D, Gourmelen M, Dina C, Chambaz J, Lacorte JM et al. 1998 A mutation in the human leptin receptor gene causes obesity and pituitary dysfunction. Nature 392 398-401.
Considine RV, Sinha MK, Heiman ML, Kriauciunas A, Stephens TW, Nyce MR, Ohannesian JP, Marco CC, McKee LJ, Bauer TL et al. 1996 Serum immunoreactive-leptin concentrations in normal-weight and obese humans. New England Journal of Medicine 334 292-295.

Crosignani PG, Ragni G, Parazzini F, Wyssling H, Lombroso G \& Perotti L 1994 Anthropometric indicators and response to gonadotrophin for ovulation induction. Human Reproduction 9 420-423.

Crosignani PG, Colombo M, Vegetti W, Somigliana E, Gessati A \& Ragni G 2003 Overweight and obese anovulatory patients with polycystic ovaries: parallel improvements in anthropometric indices, ovarian physiology and fertility rate induced by diet. Human Reproduction $\mathbf{1 8}$ 1928-1932.

Dale PO, Tanbo T, Haug E \& Abyholm T 1998 The impact of insulin resistance on the outcome of ovulation induction with low-dose follicle stimulating hormone in women with polycystic ovary syndrome. Human Reproduction 13 567-570.

Davies MJ 2006 Evidence for effects of weight on reproduction in women. Reproductive Biomedicine Online 12 552-561.

Dechaud H, Anahory T, Reyftmann L, Loup V, Hamamah S \& Hedon B 2006 Obesity does not adversely affect results in patients who are undergoing in vitro fertilization and embryo transfer. European Journal of Obstetrics, Gynecology, and Reproductive Biology 127 88-93.

Deitel M, Stone E, Kassam HA, Wilk EJ \& Sutherland DJ 1988 Gynecologic-obstetric changes after loss of massive excess weight following bariatric surgery. Journal of the American College of Nutrition 7 147-153.

Deura I, Harada T, Taniguchi F, Iwabe T, Izawa M \& Terakawa N 2005 Reduction of estrogen production by interleukin- 6 in a human granulosa tumor cell line may have implications for endometriosis-associated infertility. Fertility and Sterility 83 (Supplement 1) 1086-1092.

Dokras A, Baredziak L, Blaine J, Syrop C, VanVoorhis BJ \& Sparks A 2006 Obstetric outcomes after in vitro fertilization in obese and morbidly obese women. Obstetrics and Gynecology 108 61-69.

Duggal PS, Van Der Hoek KH, Milner CR, Ryan NK, Armstrong DT, Magoffin DA \& Norman RJ 2000 The in vivo and in vitro effects of exogenous leptin on ovulation in the rat. Endocrinology 141 1971-1976.

Dunaif A 1997 Insulin resistance and the polycystic ovary syndrome: mechanism and implications for pathogenesis. Endocrine Reviews 18 774-800.

Eid GM, Cottam DR, Velcu LM, Mattar SG, Korytkowski MT, Gosman G, Hindi P \& Schauer PR 2005 Effective treatment of polycystic ovarian syndrome with Roux-en-Y gastric bypass. Surgery for Obesity and Related Diseases 1 77-80.

El Orabi H, Ghalia AA, Khalifa A, Mahfouz H, El Shalkani A \& Shoieb N 1999 Serum leptin as an additional possible pathogenic factor in polycystic ovary syndrome. Clinical Biochemistry 32 71-75.

Ertzeid G \& Storeng R 1992 Adverse effects of gonadotrophin treatment on pre- and postimplantation development in mice. Journal of Reproduction and Fertility 96 649-655.

Ertzeid G, Storeng R \& Lyberg T 1993 Treatment with gonadotropins impaired implantation and fetal development in mice. Journal of Assisted Reproduction and Genetics 10 286-291.

Escobar-Morreale HF, Botella-Carretero JI, Alvarez-Blasco F, Sancho J \& San Millan JL 2005 The polycystic ovary syndrome associated with morbid obesity may resolve after weight loss induced by bariatric surgery. Journal of Clinical Endocrinology and Metabolism 90 6364-6369.

Escobar-Morreale HF, Villuendas G, Botella-Carretero JI, Alvarez-Blasco F, Sanchon R, Luque-Ramirez M \& San Millan JL 2006 Adiponectin and resistin in PCOS: a clinical, biochemical and molecular genetic study. Human Reproduction 21 2257-2265.

Esinler I, Bozdag G \& Yarali H 2008 Impact of isolated obesity on ICSI outcome. Reproductive Biomedicine Online 17 583-587.

Faraj M, Havel PJ, Phelis S, Blank D, Sniderman AD \& Cianflone K 2003 Plasma acylation-stimulating protein, adiponectin, leptin, and ghrelin before and after weight loss induced by gastric bypass surgery in morbidly obese subjects. Journal of Clinical Endocrinology and Metabolism 88 1594-1602.

Farooqi IS, Jebb SA, Langmack G, Lawrence E, Cheetham $\mathrm{CH}$, Prentice AM, Hughes IA, McCamish MA \& O'Rahilly S 1999 Effects of recombinant leptin therapy in a child with congenital leptin deficiency. New England Journal of Medicine 341 879-884. 
Fedorcsak P, Dale PO, Storeng R, Tanbo T \& Abyholm T 2001 The impact of obesity and insulin resistance on the outcome of IVF or ICSI in women with polycystic ovarian syndrome. Human Reproduction 16 1086-1091.

Fedorcsak P, Dale PO, Storeng R, Ertzeid G, Bjercke S, Oldereid N, Omland AK, Abyholm T \& Tanbo T 2004 Impact of overweight and underweight on assisted reproduction treatment. Human Reproduction $192523-2528$.

Ferlitsch K, Sator MO, Gruber DM, Rucklinger E, Gruber CJ \& Huber JC 2004 Body mass index, follicle-stimulating hormone and their predictive value in in vitro fertilization. Journal of Assisted Reproduction and Genetics 21 431-436.

Franks S, Kiddy D, Sharp P, Singh A, Reed M, Seppala M, Koistinen R \& Hamilton-Fairley D 1991 Obesity and polycystic ovary syndrome. Annals of the New York Academy of Sciences 626 201-206.

di Frega AS, Dale B, Di Matteo L \& Wilding M 2005 Secondary male factor infertility after Roux-en-Y gastric bypass for morbid obesity: case report. Human Reproduction 20 997-998.

Fridstrom M, Sjoblom P, Pousette A \& Hillensjo T 1997 Serem FSH levels in women with polycystic ovary syndrome during ovulation induction using down-regulation and urofollitropin. European Journal of Endocrinology 136 488-492.

Fulghesu AM, Villa P, Pavone V, Guido M, Apa R, Caruso A, Lanzone A, Rossodivita A \& Mancuso S 1997 The impact of insulin secretion on the ovarian response to exogenous gonadotropins in polycystic ovary syndrome. Journal of Clinical Endocrinology and Metabolism 82 644-648.

Gambineri A, Pelusi C, Vicennati V, Pagotto U \& Pasquali R 2002 Obesity and the polycystic ovary syndrome. International Journal of Obesity and Related Metabolic Disorders 26 883-896.

Gennarelli G, Holte J, Wide L, Berne C \& Lithell H 1998 Is there a role for leptin in the endocrine and metabolic aberrations of polycystic ovary syndrome? Human Reproduction 13 535-541.

Gesink Law DC, Maclehose RF \& Longnecker MP 2007 Obesity and time to pregnancy. Human Reproduction 22 414-420.

Glueck CJ, Wang P, Fontaine RN, Sieve-Smith L, Tracy T \& Moore SK 1999 Plasminogen activator inhibitor activity: an independent risk factor for the high miscarriage rate during pregnancy in women with polycystic ovary syndrome. Metabolism 48 1589-1595.

Glueck CJ, Wang P, Bornovali S, Goldenberg N \& Sieve L 2003 Polycystic ovary syndrome, the G1691A factor $\mathrm{V}$ Leiden mutation, and plasminogen activator inhibitor activity: associations with recurrent pregnancy loss. Metabolism 52 1627-1632.

Gonzalez RR, Caballero-Campo P, Jasper M, Mercader A, Devoto L, Pellicer A \& Simon C 2000 Leptin and leptin receptor are expressed in the human endometrium and endometrial leptin secretion is regulated by the human blastocyst. Journal of Clinical Endocrinology and Metabolism 85 4883-4888.

Gosman GG, Katcher HI \& Legro RS 2006 Obesity and the role of gut and adipose hormones in female reproduction. Human Reproduction Update 12 585-601.

Grodstein F, Goldman MB \& Cramer DW 1994 Body mass index and ovulatory infertility. Epidemiology 5 247-250.

Guelinckx I, Devlieger R \& Vansant G 2009 Reproductive outcome after bariatric surgery: a critical review. Human Reproduction Update $\mathbf{1 5}$ 189-201.

Guzick DS, Wing R, Smith D, Berga SL \& Winters SJ 1994 Endocrine consequences of weight loss in obese, hyperandrogenic, anovulatory women. Fertility and Sterility 61 598-604.

Hackl H 1973 Metabolism of glucose in the human endometrium with special reference to fertility and contraception. Acta Obstetricia et Gynecologica Scandinavica 52 135-140.

Hamilton-Fairley D, Kiddy D, Watson H, Paterson C \& Franks S 1992 Association of moderate obesity with a poor pregnancy outcome in women with polycystic ovary syndrome treated with low dose gonadotrophin. British Journal of Obstetrics and Gynaecology 99 128-131.

Hartz AJ, Barboriak PN, Wong A, Katayama KP \& Rimm AA 1979 The association of obesity with infertility and related menstural abnormalities in women. International Journal of Obesity 3 57-73.

Hassan MA \& Killick SR 2004 Negative lifestyle is associated with a significant reduction in fecundity. Fertility and Sterility 81 384-392.
Heslehurst N, Ells LJ, Simpson H, Batterham A, Wilkinson J \& Summerbell CD 2007 Trends in maternal obesity incidence rates, demographic predictors, and health inequalities in 36,821 women over a 15-year period. British Journal of Obstetrics and Gynaecology 114 187-194.

Hollmann M, Runnebaum B \& Gerhard I 1996 Effects of weight loss on the hormonal profile in obese, infertile women. Human Reproduction $\mathbf{1 1}$ 1884-1891.

Holte J, Bergh T, Gennarelli G \& Wide L 1994 The independent effects of polycystic ovary syndrome and obesity on serum concentrations of gonadotrophins and sex steroids in premenopausal women. Clinical Endocrinology 41 473-481.

Homburg R, Orvieto R, Bar-Hava I \& Ben-Rafael Z 1996 Serum levels of insulin-like growth factor-1, IGF binding protein-1 and insulin and the response to human menopausal gonadotrophins in women with polycystic ovary syndrome. Human Reproduction 11 716-719.

Howards PP \& Cooney MA 2008 Disentangling causal paths between obesity and in vitro fertilization outcomes: an intractable problem? Fertility and Sterility 89 1604-1605.

Huber-Buchholz MM, Carey DG \& Norman RJ 1999 Restoration of reproductive potential by lifestyle modification in obese polycystic ovary syndrome: role of insulin sensitivity and luteinizing hormone. Journal of Clinical Endocrinology and Metabolism 84 1470-1474.

Jayagopal V, Kilpatrick ES, Holding S, Jennings PE \& Atkin SL 2005 Orlistat is as beneficial as metformin in the treatment of polycystic ovarian syndrome. Journal of Clinical Endocrinology and Metabolism 90 729-733.

Jungheim ES, Lanzendorf SE, Odem RR, Moley KH, Chang AS \& Ratts VS 2009 Morbid obesity is associated with lower clinical pregnancy rates after in vitro fertilization in women with polycystic ovary syndrome. Fertility and Sterility 92 256-261.

Karlsson C, Lindell K, Svensson E, Bergh C, Lind P, Billig H, Carlsson LM \& Carlsson B 1997 Expression of functional leptin receptors in the human ovary. Journal of Clinical Endocrinology and Metabolism 82 $4144-4148$.

Kawamura K, Sato N, Fukuda J, Kodama H, Kumagai J, Tanikawa H, Murata M \& Tanaka T 2003 The role of leptin during the development of mouse preimplantation embryos. Molecular and Cellular Endocrinology 202 185-189.

Kiddy DS, Hamilton-Fairley D, Seppala M, Koistinen R, James VH, Reed MJ \& Franks S 1989 Diet-induced changes in sex hormone binding globulin and free testosterone in women with normal or polycystic ovaries: correlation with serum insulin and insulin-like growth factor-I. Clinical Endocrinology 31 757-763.

Kiddy DS, Hamilton-Fairley D, Bush A, Short F, Anyaoku V, Reed MJ \& Franks S 1992 Improvement in endocrine and ovarian function during dietary treatment of obese women with polycystic ovary syndrome. Clinical Endocrinology 36 105-111.

Kowalska I, Kinalski M, Straczkowski M, Wolczyski S \& Kinalska I 2001 Insulin, leptin, IGF-I and insulin-dependent protein concentrations after insulin-sensitizing therapy in obese women with polycystic ovary syndrome. European Journal of Endocrinology 144 509-515.

Krassas GE, Kaltsas TT, Pontikides N, Jacobs H, Blum W \& Messinis I 1998 Leptin levels in women with polycystic ovary syndrome before and after treatment with diazoxide. European Journal of Endocrinology 139 184-189.

Lake JK, Power C \& Cole TJ 1997 Women's reproductive health: the role of body mass index in early and adult life. International Journal of Obesity and Related Metabolic Disorders 21 432-438.

Lashen H, Ledger W, Bernal AL \& Barlow D 1999 Extremes of body mass do not adversely affect the outcome of superovulation and in vitro fertilization. Human Reproduction 14 712-715.

Lashen H, Fear K \& Sturdee DW 2004 Obesity is associated with increased risk of first trimester and recurrent miscarriage: matched case-control study. Human Reproduction 19 1644-1646.

Laughlin GA, Morales AJ \& Yen SS 1997 Serum leptin levels in women with polycystic ovary syndrome: the role of insulin resistance/hyperinsulinemia. Journal of Clinical Endocrinology and Metabolism 82 1692-1696.

Ledoux S, Campos DB, Lopes FL, Dobias-Goff M, Palin MF \& Murphy BD 2006 Adiponectin induces periovulatory changes in ovarian follicular cells. Endocrinology 147 5178-5186. 
Leenen R, van der Kooy K, Seidell JC, Deurenberg P \& Koppeschaar HP 1994 Visceral fat accumulation in relation to sex hormones in obese men and women undergoing weight loss therapy. Journal of Clinical Endocrinology and Metabolism 78 1515-1520.

Levens ED \& Skarulis MC 2008 Assessing the role of endometrial alteration among obese patients undergoing assisted reproduction. Fertility and Sterility 89 1606-1608.

Lewis G (Ed.) 2007 The Confidential Enquiry into Maternal and Child Health (CEMACH). Saving Mothers' Lives: Reviewing Maternal Deaths to Make Motherhood Safer - 2003-2005. The Seventh Report of the Confidential Enquiries into Maternal Deaths in the United Kingdom. London: CEMACH.

Licinio J, Mantzoros C, Negrao AB, Cizza G, Wong ML, Bongiorno PB, Chrousos GP, Karp B, Allen C, Flier JS et al. 1997 Human leptin levels are pulsatile and inversely related to pituitary-adrenal function. Nature Medicine 3 575-579.

Lloyd GER (Ed.) 1978 Hippocratic writings. London: Penguin Books.

Loveland JB, McClamrock HD, Malinow AM \& Sharara FI 2001 Increased body mass index has a deleterious effect on in vitro fertilization outcome. Journal of Assisted Reproduction and Genetics 18 382-386.

Maffei M, Halaas J, Ravussin E, Pratley RE, Lee GH, Zhang Y, Fei H, Kim S, Lallone R, Ranganathan S et al. 1995 Leptin levels in human and rodent: measurement of plasma leptin and ob RNA in obese and weight-reduced subjects. Nature Medicine 1 1155-1161.

Maggard MA, Yermilov I, Li Z, Maglione $M$, Newberry S, Suttorp M, Hilton L, Santry HP, Morton JM, Livingston EH et al. 2008 Pregnancy and fertility following bariatric surgery: a systematic review. Journal of the American Medical Association 300 2286-2296.

Maheshwari A, Stofberg L \& Bhattacharya S 2007 Effect of overweight and obesity on assisted reproductive technology - a systematic review. Human Reproduction Update 13 433-444.

Mantzoros CS, Dunaif A \& Flier JS 1997 Leptin concentrations in the polycystic ovary syndrome. Journal of Clinical Endocrinology and Metabolism 82 1687-1691.

Marceau P, Kaufman D, Biron S, Hould FS, Lebel S, Marceau S \& Kral JG 2004 Outcome of pregnancies after biliopancreatic diversion. Obesity Surgery 14 318-324.

Martinuzzi K, Ryan S, Luna M \& Copperman AB 2008 Elevated body mass index (BMI) does not adversely affect in vitro fertilization outcome in young women. Journal of Assisted Reproduction and Genetics 25 169-175.

Matalliotakis I, Cakmak H, Sakkas D, Mahutte N, Koumantakis G \& Arici A 2008 Impact of body mass index on IVF and ICSI outcome: a retrospective study. Reproductive Biomedicine Online 16 778-783.

Matthaei S, Stumvoll M, Kellerer M \& Haring HU 2000 Pathophysiology and pharmacological treatment of insulin resistance. Endocrine Reviews 21 585-618.

McCormick B, Thomas M, Maxwell R, Williams D \& Aubuchon M 2008 Effects of polycystic ovarian syndrome on in vitro fertilization-embryo transfer outcomes are influenced by body mass index. Fertility and Sterility 90 2304-2309.

Merhi ZO 2007 Weight loss by bariatric surgery and subsequent fertility. Fertility and Sterility 87 430-432.

Messinis IE \& Milingos SD 1999 Leptin in human reproduction. Human Reproduction Update 5 52-63.

Metwally M, Cutting R, Tipton A, Skull J, Ledger WL \& Li TC 2007 a Effect of increased body mass index on oocyte and embryo quality in IVF patients. Reproductive Biomedicine Online 15 532-538.

Metwally M, Tuckerman EM, Laird SM, Ledger WL \& Li TC $2007 \mathrm{~b}$ Impact of high body mass index on endometrial morphology and function in the peri-implantation period in women with recurrent miscarriage. Reproductive Biomedicine Online 14 328-334.

Metwally M, Ong KJ, Ledger WL \& Li TC 2008 Does high body mass index increase the risk of miscarriage after spontaneous and assisted conception? A meta-analysis of the evidence Fertility and Sterility $\mathbf{9 0}$ 714-726.

Metwally M, Amer S, Li TC \& Ledger WL 2009 An RCT of metformin versus orlistat for the management of obese anovulatory women. Human Reproduction 24 966-975.

Micic D, Macut D, Popovic V, Sumarac-Dumanovic M, Kendereski A, Colic M, Dieguez C \& Casanueva FF 1997 Leptin levels and insulin sensitivity in obese and non-obese patients with polycystic ovary syndrome. Gynecological Endocrinology 11 315-320.
Minge CE, Bennett BD, Norman RJ \& Robker RL 2008 Peroxisome proliferator-activated receptor-gamma agonist rosiglitazone reverses the adverse effects of diet-induced obesity on oocyte quality. Endocrinology 149 2646-2656.

Mioni R, Chiarelli S, Xamin N, Zuliani L, Granzotto M, Mozzanega B, Maffei P, Martini C, Blandamura S, Sicolo N et al. 2004 Evidence for the presence of glucose transporter 4 in the endometrium and its regulation in polycystic ovary syndrome patients. Journal of Clinical Endocrinology and Metabolism 89 4089-4096.

Moran L \& Norman RJ 2004 Understanding and managing disturbances in insulin metabolism and body weight in women with polycystic ovary syndrome. Best Practice \& Research. Clinical Obstetrics \& Gynaecology 18 719-736.

Morin-Papunen LC, Koivunen RM, Tomas C, Ruokonen A \& Martikainen HK 1998 Decreased serum leptin concentrations during metformin therapy in obese women with polycystic ovary syndrome. Journal of Clinical Endocrinology and Metabolism 83 2566-2568.

Morin-Papunen LC, Vauhkonen I, Koivunen RM, Ruokonen A \& Tapanainen JS 2000 Insulin sensitivity, insulin secretion, and metabolic and hormonal parameters in healthy women and women with polycystic ovarian syndrome. Human Reproduction 15 1266-1274.

Moschos S, Chan JL \& Mantzoros CS 2002 Leptin and reproduction: a review. Fertility and Sterility 77 433-444.

Mozzanega B, Mioni R, Granzotto M, Chiarelli S, Xamin N, Zuliani L, Sicolo N, Marchesoni D \& Vettor R 2004 Obesity reduces the expression of GLUT4 in the endometrium of normoinsulinemic women affected by the polycystic ovary syndrome. Annals of the New York Academy of Sciences 1034 364-374.

Mulders AG, Laven JS, Eijkemans MJ, Hughes EG \& Fauser BC 2003 Patient predictors for outcome of gonadotrophin ovulation induction in women with normogonadotrophic anovulatory infertility: a meta-analysis. Human Reproduction Update 9 429-449.

Nichols JE, Crane MM, Higdon HL, Miller PB \& Boone WR 2003 Extremes of body mass index reduce in vitro fertilization pregnancy rates. Fertility and Sterility 79 645-647.

NIH Conference 1991 Gastrointestinal surgery for severe obesity. Consensus Development Conference Panel. Annals of Internal Medicine 115 956-961.

Norman RJ \& Clark AM 1998 Obesity and reproductive disorders: a review. Reproduction, Fertility, and Development 10 55-63.

Norman RJ, Noakes M, Wu R, Davies MJ, Moran L \& Wang JX 2004 Improving reproductive performance in overweight/obese women with effective weight management. Human Reproduction Update $\mathbf{1 0}$ 267-280.

Norman RJ, Dewailly D, Legro RS \& Hickey TE 2007 Polycystic ovary syndrome. Lancet 370 685-697.

Padwal RS \& Majumdar SR 2007 Drug treatments for obesity: orlistat, sibutramine, and rimonabant. Lancet 369 71-77.

Panidis D, Farmakiotis D, Rousso D, Kourtis A, Katsikis I \& Krassas G 2008 Obesity, weight loss, and the polycystic ovary syndrome: effect of treatment with diet and orlistat for 24 weeks on insulin resistance and androgen levels. Fertility and Sterility 89 899-906.

Pasquali R \& Casimirri F 1993 The impact of obesity on hyperandrogenism and polycystic ovary syndrome in premenopausal women. Clinical Endocrinology 39 1-16.

Pasquali R \& Gambineri A 2006 Metabolic effects of obesity on reproduction. Reproductive Biomedicine Online 12 542-551.

Pasquali R, Casimirri F \& Vicennati V 1997 Weight control and its beneficial effect on fertility in women with obesity and polycystic ovary syndrome. Human Reproduction 12 (Supplement 1) 82-87.

Pasquali R, Gambineri A, Biscotti D, Vicennati V, Gagliardi L, Colitta D, Fiorini S, Cognigni GE, Filicori M \& Morselli-Labate AM 2000 Effect of long-term treatment with metformin added to hypocaloric diet on body composition, fat distribution, and androgen and insulin levels in abdominally obese women with and without the polycystic ovary syndrome. Journal of Clinical Endocrinology and Metabolism 85 2767-2774.

Pettigrew R \& Hamilton-Fairley D 1997 Obesity and female reproductive function. British Medical Bulletin 53 341-358.

Pierre P, Froment P, Negre D, Rame C, Barateau V, Chabrolle C, Lecomte P \& Dupont J 2009 Role of adiponectin receptors, AdipoR1 and AdipoR2, in the steroidogenesis of the human granulosa tumor cell line, KGN. Human Reproduction 24 2890-2901. 
Poretsky L, Cataldo NA, Rosenwaks Z \& Giudice LC 1999 The insulinrelated ovarian regulatory system in health and disease. Endocrine Reviews 20 535-582.

Rich-Edwards JW, Goldman MB, Willett WC, Hunter DJ, Stampfer MJ, Colditz GA \& Manson JE 1994 Adolescent body mass index and infertility caused by ovulatory disorder. American Journal of Obstetrics and Gynecology 171 171-177.

Rivier C \& Vale W 1990 Cytokines act within the brain to inhibit luteinizing hormone secretion and ovulation in the rat. Endocrinology 127 849-856.

Robker RL 2008 Evidence that obesity alters the quality of oocytes and embryos. Pathophysiology 15 115-121.

Rosenbaum D, Haber RS \& Dunaif A 1993 Insulin resistance in polycystic ovary syndrome: decreased expression of GLUT-4 glucose transporters in adipocytes. American Journal of Physiology 264 E197-E202.

Rouru J, Anttila L, Koskinen P, Penttila TA, Irjala K, Huupponen R \& Koulu M 1997 Serum leptin concentrations in women with polycystic ovary syndrome. Journal of Clinical Endocrinology and Metabolism 82 1697-1700.

Rubino F, Gagner M, Gentileschi P, Kini S, Fukuyama S, Feng J \& Diamond E 2004 The early effect of the Roux-en-Y gastric bypass on hormones involved in body weight regulation and glucose metabolism. Annals of Surgery $240236-242$.

Salha O, Dada T \& Sharma V 2001 Influence of body mass index and selfadministration of hCG on the outcome of IVF cycles: a prospective cohort study. Human Fertility 4 37-42.

von Schoultz B \& Carlstrom K 1989 On the regulation of sex-hormonebinding globulin - a challenge of an old dogma and outlines of an alternative mechanism. Journal of Steroid Biochemistry 32 327-334.

Senturk LM \& Arici A 1998 Leukemia inhibitory factor in human reproduction. American Journal of Reproductive Immunology 39 144-151.

Sir-Petermann T, Piwonka V, Perez F, Maliqueo M, Recabarren SE \& Wildt L 1999 Are circulating leptin and luteinizing hormone synchronized in patients with polycystic ovary syndrome? Human Reproduction 14 1435-1439.

Spandorfer SD, Kump L, Goldschlag D, Brodkin T, Davis OK \& Rosenwaks Z 2004 Obesity and in vitro fertilization: negative influences on outcome. Journal of Reproductive Medicine 49 973-977.

Stamets K, Taylor DS, Kunselman A, Demers LM, Pelkman CL \& Legro RS 2004 A randomized trial of the effects of two types of short-term hypocaloric diets on weight loss in women with polycystic ovary syndrome. Fertility and Sterility 81 630-637.

Steinkampf MP, Hammond KR, Nichols JE \& Slayden SH 2003 Effect of obesity on recombinant follicle-stimulating hormone absorption: subcutaneous versus intramuscular administration. Fertility and Sterility $\mathbf{8 0}$ 99-102.

Straus DS 1984 Growth-stimulatory actions of insulin in vitro and in vivo. Endocrine Reviews 5 356-369.

Strowitzki T, von Eye HC, Kellerer M \& Haring HU 1993 Tyrosine kinase activity of insulin-like growth factor $\mathrm{I}$ and insulin receptors in human endometrium during the menstrual cycle: cyclic variation of insulin receptor expression. Fertility and Sterility 59 315-322.

Styne-Gross A, Elkind-Hirsch K \& Scott RT Jr 2005 Obesity does not impact implantation rates or pregnancy outcome in women attempting conception through oocyte donation. Fertility and Sterility 83 1629-1634.

Swain JE, Dunn RL, McConnell D, Gonzalez-Martinez J \& Smith GD 2004 Direct effects of leptin on mouse reproductive function: regulation of follicular, oocyte, and embryo development. Biology of Reproduction 71 1446-1452.

van Swieten EC, van der Leeuw-Harmsen L, Badings EA \& van der Linden PJ 2005 Obesity and clomiphene challenge test as predictors of outcome of in vitro fertilization and intracytoplasmic sperm injection. Gynecologic and Obstetric Investigation 59 220-224.

Tamer Erel C \& Senturk LM 2009 The impact of body mass index on assisted reproduction. Current Opinion in Obstetrics and Gynecology 21 228-235.

Tang T, Glanville J, Hayden CJ, White D, Barth JH \& Balen AH 2006 Combined lifestyle modification and metformin in obese patients with polycystic ovary syndrome. A randomized, placebo-controlled, doubleblind multicentre study. Human Reproduction 21 80-89.

Teitelman M, Grotegut CA, Williams NN \& Lewis JD 2006 The impact of bariatric surgery on menstrual patterns. Obesity Surgery 16 1457-1463.
Terranova PF \& Rice VM 1997 Review: cytokine involvement in ovarian processes. American Journal of Reproductive Immunology 37 50-63.

The ESHRE Capri Workshop Group 2006 Nutrition and reproduction in women. Human Reproduction Update 12 193-207.

Toulis KA, Goulis DG, Farmakiotis D, Georgopoulos NA, Katsikis I, Tarlatzis BC, Papadimas I \& Panidis D 2009 Adiponectin levels in women with polycystic ovary syndrome: a systematic review and a metaanalysis. Human Reproduction Update 15 297-307.

Trischitta V 2003 Relationship between obesity-related metabolic abnormalities and sexual function. Journal of Endocrinological Investigation 26 62-64.

Tsagareli V, Noakes M \& Norman RJ 2006 Effect of a very-low-calorie diet on in vitro fertilization outcomes. Fertility and Sterility 86 227-229.

Van Blerkom J, Antczak M \& Schrader R 1997 The developmental potential of the human oocyte is related to the dissolved oxygen content of follicular fluid: association with vascular endothelial growth factor levels and perifollicular blood flow characteristics. Human Reproduction 12 1047-1055.

Vicennati V, Gambineri A, Calzoni F, Casimirri F, Macor C, Vettor R \& Pasquali R 1998 Serum leptin in obese women with polycystic ovary syndrome is correlated with body weight and fat distribution but not with androgen and insulin levels. Metabolism 47 988-992.

Wang JX, Davies M \& Norman RJ 2000 Body mass and probability of pregnancy during assisted reproduction treatment: retrospective study. BM) 321 1320-1321.

Wass P, Waldenstrom U, Rossner S \& Hellberg D 1997 An android body fat distribution in females impairs the pregnancy rate of in-vitro fertilizationembryo transfer. Human Reproduction 12 2057-2060.

Watanobe H \& Hayakawa Y 2003 Hypothalamic interleukin-1 beta and tumor necrosis factor-alpha, but not interleukin-6, mediate the endotoxin-induced suppression of the reproductive axis in rats. Endocrinology 144 4868-4875.

Wattanakumtornkul S, Damario MA, Stevens SA, Thornhill AR \& Tummon IS 2003 Body mass index and uterine receptivity in the oocyte donation model. Fertility and Sterility $80336-340$.

White DM, Polson DW, Kiddy D, Sagle P, Watson H, Gilling-Smith C, Hamilton-Fairley D \& Franks S 1996 Induction of ovulation with lowdose gonadotropins in polycystic ovary syndrome: an analysis of 109 pregnancies in 225 women. Journal of Clinical Endocrinology and Metabolism 81 3821-3824.

Wittemer C, OhI J, Bailly M, Bettahar-Lebugle K \& Nisand I 2000 Does body mass index of infertile women have an impact on IVF procedure and outcome? Journal of Assisted Reproduction and Genetics 17 547-552.

Wood JR \& Strauss JF III 2002 Multiple signal transduction pathways regulate ovarian steroidogenesis. Reviews in Endocrine and Metabolic Disorders 3 33-46.

Yang WS, Lee WJ, Funahashi T, Tanaka S, Matsuzawa Y, Chao CL, Chen CL, Tai TY \& Chuang LM 2001 Weight reduction increases plasma levels of an adipose-derived anti-inflammatory protein, adiponectin. Journal of Clinical Endocrinology and Metabolism 86 3815-3819.

Yen SS, Vela P \& Rankin J 1970 Inappropriate secretion of folliclestimulating hormone and luteinizing hormone in polycystic ovarian disease. Journal of Clinical Endocrinology and Metabolism 30 435-442.

Zaadstra BM, Seidell JC, Van Noord PA, te Velde ER, Habbema JD, Vrieswijk B \& Karbaat J 1993 Fat and female fecundity: prospective study of effect of body fat distribution on conception rates. BMJ 306 484-487.

Zachow RJ \& Magoffin DA 1997 Direct intraovarian effects of leptin: impairment of the synergistic action of insulin-like growth factor-I on follicle-stimulating hormone-dependent estradiol-17 $\beta$ production by rat ovarian granulosa cells. Endocrinology 138 847-850.

Zamorano PL, Mahesh VB, De Sevilla LM, Chorich LP, Bhat GK \& Brann DW 1997 Expression and localization of the leptin receptor in endocrine and neuroendocrine tissues of the rat. Neuroendocrinology 65 223-228.

Received 1 February 2010

First decision 2 March 2010

Revised manuscript received 12 April 2010

Accepted 15 April 2010 